\title{
INTERESTS IN LAND IN THE CUSTOMARY LAW OF GHANA - A NEW APPRAISAL
}

\author{
SAMUEL K. B. ASANTE†
}

INTRODUCTION

THE ascertainment of contemporary customary law in Africa poses formidable problems to the jurist who refuses to be contained by the orthodox "authorities." There is indeed no lack of textbook assertions or judicial pronouncements on the content of customary law. However, in a country like Ghana where changing social and economic forces have progressively eroded the traditional social mechanism, even the most "authoritative" formulation of customary doctrine by the courts still leaves one yearning for what Cohen calls the "hard coin of social fact in place of paper legalities." The very nature of customary law makes reference to contemporary practice and usage in society an integral part of the legal process. Customary law defies the Kelsenite dichotomy between the realm of "ought" and the domain of "is." There can be no retreat to a remote and unsullied haven of logically coherent juristic norms, and certainly the framers of the Ghanaian Constitution had no stuch illusion when they defined the corpus of the customary law as comprising "rules of law which by custom are applicable to particular communities in Ghana."2 This definition postulates an empirical reference for the content of the law, reaffirming the truism that customary law is grounded on the customs actually prevailing in the community.

Yet a study of the decisions of Ghanaian courts discloses a disconcerting conflict between judicial enunciation of customary doctrine and contemporary practice in the social process. This conflict is hardly surprising. In Ghana, the reception of English common law meant the adoption of English legal traditions and attitudes. For some ninety years, ${ }^{3}$ the customary law has been administered in the upper levels of the judicial hierarchy by British or British trained judges, whose jurisprudential "take-off" is analytical positivism, and

TLecturer in Law, University of Ghana; Sterling Fellow, Yale Law School. The author gratefully acknowledges the encouragement and assistance of Professor Elias Clark of the Yale Law School, and Mr. Justice N. A. Ollennu of the Supreme Court of Ghana.

1. Cohen, The Problems of a Functional Jurisprudence, 1 MODERN L. REv. 5 (1938).

2. Interpretation Act $\$ 18(1)$, Acts of GHANA (1960).

3. Since the Supreme Court Ordinance, 1876 , as reenacted, 1 LAws of THE GoLD COAST c. 4 (1937).

4. In the recent case of Sasraku v. David, [1959] Ghana L. Rep. 7, where the cchtral issue revolved around the alienability of land in Ashanti, the enterprising trial judge ventured to examine a wide spectrum of legal, sociological and political materials including dispatches to the British Colonial Office by the Colonial Administration, and a work on the modern political system of Ashanti. This excursus into the "extra-legal world" for the purpose of establishing that there had, in fact, been a change in the customary 
who regard a stringent doctrine of stare decisis as an axiom of the judicial process. ${ }^{5}$ Thus a meaningful and scientific clarification, as well as a purposeful application, of contemporary customary law has been menaced by a tradition which restricts the orbit of the law to the narrow confines of authoritative decisions, and strictly commits decision-makers of today to the dubious wisdom of past experierice. Nowhere is this cleavage between textbook law and social reality more glaring than in the customary land law of Ghana.

This article is concerned with a reappraisal of the customary scheme of interests in land in the light of the changing conditions. First, the traditional scheme of interests in land will be outlined; second, an attempt will be made to analyze the various social and economic pressures impinging on the traditional scheme; third, the reaction of the courts to these phenomena will be considered and, finally, it is proposed to advert briefly to the increasing involvement of the Central Government in the administration and regulation of land and its impact on the customary scheme of interests in land.

\section{A. Preliminary Factors}

Since the Ghanaian citizenry is composed of different ethnic groups, the purists would deny the existence of any comprehensive system of customary law on the ground that the systems applicable to the various communities and ethnic groups have little in common. ${ }^{6}$ On the other hand, the courts have, over the years, pursued a policy of gradual integration, somewhat in the manner of the royal judges of Norman England, leading to the evolution of a body of principles which they have proclaimed to be of universal application in the country. A dictum of Judge Lingley candidly summarizes the judicial attitude to the eradication of local peculiarities in customary jurisprudence.

This court cannot allow local customs to override general principles and practice in these days of changing conditions. ${ }^{7}$

This universalist approach also pervades Mr. Justice Ollennu's recent work on customary land law, ${ }^{8}$ which makes a valiant attempt to telescope all the various bodies of legal doctrine in this area into a tidy and well-articulated schema.

usages of the Ashanti with respect to the alienation of land, did not pass without a mild rebuke by the Court of Appeal. Delivering the opinion of the appellate tribunal, Granville Sharp, J.A., observed:

The learned Judge made exhaustive research into the question whether land in Ashanti is capable of alienation by sale, much of zohich rescarch it is true entered channels which could not be expected to lead very far in a Court of lonc.

Id. at 13 (emphasis added).

In fact, the Court held that land was alienable in Ashanti, but only because "authorilative" -i.e., legal - writers said so. This artificial distinction between authoritative works and other valuable works in the social sciences can only be meaningiul to a blind positivist.

5. See Asante, Stare Decisis in the Suprene Conrt of Ghana, 1 U. Grasia L.J. 52 (1964).

6. See, e.g., Allott's comment on Kotei v. Asere Stool, 5 J. African L. 180-81 (1961).

7. Biei v. Akomea, 1 West Africa Law Reports 174 (1956) [cited hereafter as W. Afr. L. Rep.].

8. Ollennu, Princtples of Customary Land Law in Grana (1962). 
It is submitted, however, that neither the purist theory of strict heterogeneity nor the doctrine of universalism by judicial fiat is particularly helpful in the clarification of customary land law. Indigenous systems of land ownership in Ghana would seem to fall into two broad categories depending on the structure of the political and social organization of the community in question. In the highly centralized traditional states, ${ }^{0}$ exhibiting a well-entrenched political authority as well as a high level of social integration, concepts of land ownership were complicated by questions of political sovereignty or paramountcy.

In these states the stool was at once overlord of the state and owner of the land within its territorial boundaries. The scheme of interests in land was anchored on the fundamental premise that absolute ownership of the land was exclusively vested in the stool, with the subjects merely enjoying rights of beneficial user or usufruct. Furthermore, the distribution of these ust1fructuary rights revolved around the political and social ordering in the state, so that the gradation of proprietary interest was inseparable from social and constitutional status. Quantum was referrable to immunities from restrictions on user, and these immunities increased as one climbed the political ladder. At the apex of the hierarchy was the stool, the next rung was occupied by the sub-stool, then came the family and finally the individual subject. In short, the modern distinction between public and private law had no application to traditional systems of land ownership in the centralized states. In the less centralized political systems, ${ }^{10}$ ownership of community land was not an inevitable attribute of political sovereignty, and there was accordingly no concept of the stool's dominium of land within its territorial botundaries. Furthermore, there was no doctrinal impediment to the acquisition of absolute ownership by the individual subject. This article will deal exclusively with the scheme of interests in the centralized states - a much more complex phenomenon than the scheme in the less centralized states. What follows, therefore, does not pretend to be universally valid in Ghana.

9. As for example Ashanti and Akim Abuakwa. See DangunIr, Akan LAws AN1 Customs 214 (1928) ; Rattray, Ashanti Law and Constitution c. 33 (1929). The component divisions of the $\mathrm{Ga}$ state appear to be well integrated and highly centralized, though the Ga state itself lacks such cohesion.

10. E.g., The Northern political systems and also the Fantes. See CasenY-HAyrotw, Goxd CoAst NAtTve Instrtutrons 43 (1903), where in discussing the position of the Paramount Chief or King of a Fante state, he says:

Now what are the rights of the King in respect of the lands of a community. The King qua King does not own all the lands of the State. The limits of his proprietary rights are strictly defined. There are first of all lands which are the essential property of the King. These he can deal with as he pleases, but with the sanction of his family. Second, there are lands attached to the stool which the King can deal with only with the consent of his councillors. Third, there are the general lands of the State over which the King exercises paramountcy. It is a sort of sovercign oversight which doesn't carry with it the ownership of any particular land. It is not even ownership in a general way in respect of which, per se, the King can have a locis standi in a court of law. To him indeed belongs the power of ratifying and confirming what the subject grants, though he may not himself grant that which is given. 
From the viewpoint of Ghanaian customary law, property may be divided into four classifications: land, that is to say, the soil or earth; things savoring of land such as houses, huts and farms; movables; and intangible property such as medical or magical formulae. This classification has legal, sociological and religious significance since such questions as alienability, the quantum of proprietary interest which an individual can hold and the powers of customary fiduciary functionaries over corporate property are substantially affected by the nature of the property in question. Property may also be classified into three broad groups according to the character of the owning entity: stool, family and individual property. This classification is pertinent to questions relating to the management of property, conveyancing forms and the extent of beneficial enjoyment.

Traditional thinking drew a sharp distinction between the soil or earth and the tangible fruits of man's endeavor thereon. Farms, houses and other buildings were not considered land and were not subject to the doctrinal restraints on alienation which characterized land law. 11 Nor did the customary conception of "land" encompass incorporeal interests or usufructuary rights. -But this traditional view has been rejected in recent legislation and commentary. ${ }^{12}$ The Ghana Interpretation Act of 1960 follows the broad English definition of land $: 13$

'Land' includes land covered by water, any house, building or structure whatsoever, and any estate, interest or right in, to or over land or water.14

It is not clear whether the above definition disposes of the customary conception of land. It is arguable that the Interpretation Act is merely concerned to postulate the purview of the term "land" for the purposes of legislation. ${ }^{15}$ It did not prevent the Supreme Court from applying the traditional definition of land in the case of Dadzie $v$. Kokof ${ }^{16}$ in which the court held that ownership of cocoa farms was to be strictly distinguished from ownership of the land on which they were situated, and that the successor to the land had no auto-

11. See Ratrray, Ashanti Law and Constrrution 340, 349 (1929).

12. OllenNu, op. cit. supra note 8, at 1:

The term land as understood in customary law has a wide application. It includes the land itself, i.e., the surface soil; it includes things on the soil which are enjoyed with it as being part of the land by nature, c.g., rivers, streams, lakes, lagoons, creeks, growing trees like palm trees and dawadawa trees, or as being artificially fixed to it like houses, buildings and structures whatsoever; it also includes any estate, interest or right in, to or over the land or over any of the other things which land denotes, e.g., the right to collect snails, herbs, or to hunt on land.

13. Law of Property Act, 1925, $15 \& 16$ Geo. 5, § 205(1):

"Land" includes land of any tenure and mines and minerals, whether or not held apart from the surface, buildings or parts of buildings (whether the division is horizontal, vertical or made in any other way) and other corporeal hereditaments; also a manor, an advowson and a rent and other incorporeal hereditaments, an casement right, privilege or benefit in over, or derived from land.

14. Interpretation Act § 32, Acts of GHANA (1960).

15. Some support for this view may be derived from the wording of $\S 1$.

16. Cyclostyled judgments of the Supreme Court, Jan. - June, 1961. 
matic claim to such farms, where these had been made by another person under a license granted by the decedent.

A meaningful discussion of customary land law necessarily entails an excursus into the religious aspect of land. Throughout Ghana, traditional philosophy ascribed a sacred significance to land. According to the Northern Ethnic groups, land was the property of the earth spirit who was the giver of life and the wherewithal to live. ${ }^{17}$ Similarly the Gas attributed ownership of land to sacred lagoons, ${ }^{18}$ while the Ashantis regarded it as a supernatural female force - the inexhaustible source of sustenance and the provider of man's most basic needs. ${ }^{18}$ She was "helpful if propitiated and harmftl if ignored." Land was the sanctuary for the souls of the departed ancestors, and a reference to a place as the burial grove of the ancestors had a deep emotive significance. Indeed another important premise of the religious significance of land was the deep-seated idea that land belonged to the ancestors. In the celebrated words of the late Nana Sir Ofori Atta I, a distinguished traditional dignitary :

[L] and belongs to a vast family of whom many are dead, a few are living and countless host are still unborn. ${ }^{20}$

Concepts of land ownership were thus bound up with the cult of ancestral worship. This cult is predicated on the belief that the departed ancestors superintend the earthly affairs of their living descendants, protecting them from disaster and generally ensuring their welfare, but demanding in return strict compliance with time-honored ethical prescriptions. Reverence for ancestral spirits dictated the preservation of land which the living shared with the dead. In effect land was an ancestral trust committed to the living for the benefit of themselves and generations yet unborn. Land, then, was the most valuable heritage of the whole community, and cottd not be lightly parted with.

That eternal corporation of the past, present and future was the state, symbolized by the stool. It only needed a well-integrated and centralized political system, as in Ashanti, to extend the religious idea of ancestral ownership of land to the legal doctrine of the stool's absolute ownership of all land within its territorial boundaries. ${ }^{21}$ The Chief's position vis-a-vis stool land was that of a fiduciary. As the top executive functionary he had authority to manage

17. See Cardinald, Natives of the Northern Territories of the Golp Const 17 (1921).

18. Manoukian, Akan and Ga-Adangbe Peoples of the Gold Coast 86 (1950).

19. Busta, The Position of the Chief in the Modern Political System af Ashanti 40 (1951).

20. Quoted in Ollensu, op. cit. supra note 8, at 4.

21. Busia, op. cit. supra note 19, at 44 :

In Ashanti the object which symbolized the unity of the ancestors and their descendants was the stool which the chief occupied. In any Ashanti village the inquirer was informed, "The land belongs to the stool," or "The land belongs to the chicf." Further investigation revealed that both expressions meant the same thing: "The land belongs to the ancestors." 
and administer the property, but he was required to do so in the interest of his subjects.

\section{B. The Traditional Scheme of Interests in Lawd}

A central consequence of traditional religious and political dogma was the attribution of the unqualified ownership of all land within the state to the stool. Title to land was one and indivisible and it was exclusively vested in the stool. Before the indigenous economy became predominantly agricultural a stool subject could not claim exclusive rights of possession and user over any part of the land: "every member of the tribe had equal rights to wander over and hunt upon the land which belonged to the group."22 Later, when people settled down to farming as the main economic activity, and stool subjects reduced portions of land into their possession for the purposes of cultivation, there developed the concept of the subject's usufructuary right to stool land, that is to say, the right to occupy, till, or otherwise enjoy an unappropriated portion of stool land and to appropriate the fruits of such user. This right of beneficial user in no way derogated from the allodial title of the stool; to use Lord Haldane's words, the usufructuary right was "a mere qualification of or burden on the radical or final title of the Sovereign. . .."23 Traditional ideas drew a sharp distinction between the subjects' right of beneficial user in stool land, and the stool's absolute ownership thereof. An Ashanti saying runs: "The farm [meaning the farm produce] is mine, the soil is the Chief's." User, however long, could never ripen into ownership ;"25 there was no equivalent of the Anglo-American idea of prescription. As a consequence of this scheme no land could be ownerless. ${ }^{28}$

The usufruct, as we have noted, was not a species of ownership; it consisted of perpetual rights of beneficial user in re aliena - the stool's land. Stool subjects had an inherent right to a usufruct in any unappropriated portion of state land; accordingly the bare facts of effective occupation or cultivation by a subject were enough to establish his usufructuary interest without the necessity of a formal grant by the stool. But a second form of acquisition was by express grant by the stool. Such grants were usual in the case of town lands, where strict supervision of allocation of parcels was necessary for the purposes of town planning. Finally, a subject could transfer his usufruct to a fellow-subject.

22. RatTRAY, op. cit. sipra note 11, at 361 .

23. Tijani v. Secretary, Southern Nigeria, [1921] 2 A.C. 399, 403.

24. RATTRAY, op. cit. supra note 11 , at 347.

25. See Kuma v. Kuma, 5 West Africa Court of Appeals 4 [cited hereafter as W. Afr. Ct. App.] (Privy Council 1938).

26. Wiapa v. Solomon, [1905] 2 Renner's Gold Coast \& Nigeria Reports 410 [cited hereafter as Ren.]. This principle was used as an effective weapon by the indigenous peoples against the attempts of the British Colonial Government to declare unoceupied lands as Crown lands. The Ghanaians successfully resisted appropriation by the Colonial Government with the contention that all vacant lands were already vested in the stools which had jurisdiction over them. 
The usufruct was usually held by a corporate body - the sub-stool, lineage or family; but there was no doctrinal prohibition of its acquisition by an individual. The greater incidence of corporate holding was a result of economic convenience; traditional social process employed co-operative endeavor to accomplish the formidable tasks of clearing and cultivating large tracts of inpenetrable forest lands, and the collective efforts of kinsmen invariably resulted in the creation of corporate or family property. But there was nothing to prevent an enterprising individual from establishing his own private concern by his own unaided exertions. In an agricultural economy where stbsistence depended on full and extensive exploitation of land, public policy leaned towards liberal appropriation of lands by families and individuals alike. ${ }^{27}$

The usufruct was potentially perpetual $;^{28}$ it subsisted as long as the subject or his successors continued to acknowledge the superior title of the stool. The proviso for the recognition of the stool's title did not limit the stibject's quantum of interest which persisted so long as the subject or his successors retained their status as subjects, but indicated the political basis on which the subjects' proprietary interest, as well as his other civic rights, rested. The usufruct was heritable and devolved on the family of the subject on his death intestate. It lapsed upon express abandonment of the land in question or failure of successors, whereupon the stool resumed its dominitum free from encumbrances.

The security of the subject's usufruct was reasonably assured. The stool could not alienate it to another person without the usufructuary's consent. Nor did the stool's dominium carry the right to divest the subject of his interest except for a recognized and specific public cause. No compensation was payable in consequence of such dispossession, ${ }^{29}$ but the inclination and oppor tunity for such divestiture were extremely rare in olden times.

The usufructuary had an exclusive right to the possession of the land subject to his usufruct, which was fully guaranteed against invasion by other subjects. User of the surface of the land was virtually unrestricted; the usufructuary could cultivate, build or enjoy the land in any manner he chose provided he did not invade the stool's right to the minerals and treasure-trove. Otherwise there was nothing in the nature of "incidents of tenure." True, the subject had to render prescribed services to the stool, such as offering the first fruits of his annual harvest or presenting specific portions of game killed on the land. But these services are not analogous to feudal incidents of tenure, for they were exigible, not in consequence of a proprietary arrangement between stool

27. The more land a Chief gave away to others in olden times "to look aiter for him" or "to eat upon," the greater became the number and wealth of his subjects. All this wealth ... the head stool rightly regarded as eventually accruing to it. RATTRAX, op. cit. stpra note 11, at 365.

28. Pogucki, The Main Principles of Rural Land Tentre, in WiLs, Aaricultune aNd LAND Use IN GHaNa 179, 180 (1962).

29. Fortes, The Ashanti Social Survey: A Preliminary Report, 6 Ruodes-LivinaSTONE J. 1, 13 (1948). 
and subject, but by virtue of the political and kinship ties binding them. Thus the general obligation to perform services to the stool persisted even where the subject was no longer resident in his own state. The relationship between a stool and its subject was primarily political, though it undoubtedly had proprietary implications such as the subjects' inherent right to a usufruct, and his obligation to present part of his annual produce to the stcol.

The inferior quality of the usufruct came into sharp relief in the matter of alienation. Here, customary notions drew a subtle distinction between the tangible embodiment of beneficial user, such as farms and buildings, and the bare usufruct, that is, the right to beneficial user which the subject acquired by occupation, grant or transfer. The subject was virtually unrestricted in the disposition of the "fruits of his labor." He could alienate these by sale, pledge or gift without prior reference to the stool. He could also dispose of them by samansize - the customary noncupative will - which was effective if ratified by the decedent's family. Alienation of the bare usufruct, however, savored of alienation of the land itself, and thus raised the question of the political allegiance of the new usufructuary holder. The transfer of such interest to a fellow-subject was admissible since the transferee would in any case be under an obligation to render the appropriate services to the stool. But alienation to a stranger was strictly forbidden without the prior consent of the stool.31 Of course, outright alienation of the land itself fell completely outside the legal competence of the subject-usufructuary. "Nemo dat quod non habet." Only the stool could effect a disposition of such far-reaching consequences.

Although traditional legal doctrine proclaimed the usufruct to be heritable and potentially perpetual, permanent occupation was extremely rare during the early agricultural phase. The agricultural technique predominantly employed in this period was shifting cultivation, ${ }^{32}$ which entailed frequent abandonment of plots previously cultivated. Land was cultivated, abandoned and then became unencumbered stool land in a rapid succession, and the phenomenon of frequent reverter to the stool reinforced the concept of the stool's dominium of land within the state. Thus Governor Maxwell, who sought to promote individual ownership in the country at the turn of the century, encouraged Ghanaians to abandon shifting cultivation on the ground that "however often they resorted to a given piece of land to cultivate it, the natives acquired no rights to the land itself." The usufruct, as it were, existed "in nubibus," now and then finding concrete expression by way of attachment to a series of parcels and perfectly compatible with the solid and permanent interest vested in the stool. Similarly, the rickety constructions which passed as buildings in the early days did not foster permanent occupation.

The stool's right of sovereignty and ownership were strongest with respect to stool land unencumbered by the subject's usufruct. Here ownership was

30. BUSIA, op. cit. supra note 19 , at 57-60.

31. RATTRAY, op. cit. supra note 11 , at 363 .

32. Land rotation and shifting cultivation are defined and discussed in WuLs, AGrsculture and Land Use in Ghana 201-03 (1961). 
absolute in every sense of the word, admitting of no legal limitations on user, duration and alienation. The bulk of stool revenue was accounted for by profits accruing from the exploitations of these lands. The powers of management and control were vested in the chief, but he was strictly required to consult his councillors in the administration of the property, and, as we have pointed out, the whole management was subject to the cardinal fiduciary obligation to administer the property in the interest of the stool.

However, in regard to stool land encumbered by the subject's usufruct, the stool's dominium was somewhat reduced to "a pure legal estate to which beneficial enjoyment was not attached." Here ownership connoted a sort of doctrinal myth, rigorously asserted and respectfully acknowledged, but bereft of all significant economic content. Whatever the juridical nature of the ustlfruct, it invested the subject with indefinite rights of user which did not admit of participation by the stool except in the case of minerals. As already indicated, the services rendered by the subject to the stool were more in the nature of taxation than rent. The only significant legal consequences of the stool's dominium of land in the occupation of subjects were its exclusive competence to effect outright alienation of the land and the possibility of reverter in the case of abandonment or failure of successors - a right equally claimed by stools which did not assert dominium of state land. The titimate right of a state to bona vaccantia need not involve a proprietary concept at all. It may be confidently stated that developments in the customary scheme of interests within the past hundred years have been marked by the progressive erosion of the stool's dominium by an enhanced usufruct.

We have discussed the two basic interests in the traditional schema. However, there were gradations of the usufruct corresponding to the political hierarchy. Thus although a sub-stool was merely entitled to a usufruct according to strict doctrine, this interest assumed a status virtually indistinguishable from the stool's dominium in the case of a powerful sub-stool with a sizeable territorial division. At the bottom of the hierarchy of interests was the interest of an individual member in a family usufruct. His interest was, of course, inferior to that of a sole usufructuary. The former was entitled to exclusive possession and user of part of the family estate allocated to him by the head of the family, who, however, enjoyed unrestricted rights of entry upon all the land subject to the family usufruct. But an individual member could not transfer any interest in the corporate holding. Indeed, family property was unseverable and indivisible (except upon formal severance of family ties) ; it could not be disposed of by will.

The stool also often granted rights of beneficial user to strangers for a nominal consideration, such as periodical services rendered to the stool. These arrangements were in the nature of licenses and did not admit of alienation by the stranger-grantee. The interest was not heritable, though in practice the stool allowed successors to avail themselves of the rights so granted. 


\section{The Impact of Social and Economic Developarents \\ On the Traditional Scheme of Interests in Land}

As intimated earlier, treatises and judicial pronouncements often portray African law as a body of rigid rules impervious to the onslaught of economic and social pressures. The charge that a particular proposition is "repugnant to native ideas" is a favorite make-weight of judges schooled in the positivist tradition. Thus the cases rarely acknowledge that changes do occur in the customary legal process, and this pretense necessarily thwarts any meaningful investigation, by the courts, into the extra-legal forces impinging on the development of the law. A notorious example of this conception of fossilized customary law is the hallowed authority which the Courts accorded to the oft-quoted declaration of Chief Justice Rayner: "Land belongs to the community, the village or the family, never to the individual." This statement was made in a report on land tenure, prepared in 1898 with reference to southwestern Nigeria; it was subsequently endorsed by the Privy Council in 1921 ss as a general principle of West African Native Law, and religiously applied by the superior courts of West Africa, as well as the Privy Council, for some forty years thereafter, with little regard for the momentous social changes in West Africa during that crucial period.

What follows is therefore an exercise in realism - an attempt to clarify the law in action "in place of paper legalities." Under this analysis four factors emerge as profoundly affecting the traditional schema, the growth of commercial agriculture, the emergence of revolutionary attitudes to alienation of land, the influence of English juristic ideas, forms and techniques and finally the general decline of traditional authority.

\section{Commercialized Agriculture and Permanent Cultization}

Ghana is a predominantly agricultural country, but the character and pattern of agriculture have undergone a radical metamorphosis within the last hundred years. Before the mid-nineteenth century, agriculture involved only peasant farming for food crops in a typical subsistence economy. Farmers resorted to shifting cultivation and land rotation, not only as established patterns of agricultural behavior, but as a means of preserving the soil's fertility. Now the prevalence of cash crops like cocoa, coffee, coconut, kola and shallot, grown for export, has led to the commercialization of agriculture throughout the country. ${ }^{34}$ These cash crops, unlike subsistence crops, are the products of perennial trees which continue yielding for decades. Commercial agriculture therefore inaugurated permanent cultivation, and disrupted the classical usufruct. The economic yields of commercial agriculture led to a high demand for land as a commodity of commerce. ${ }^{35}$

33. Tijani v. Secretary, Southern Nigeria, [1921] 2 A.C. 399, 404.

34. Thus Polly Hill's recent work on the Migrant Cocoa-farmers of Southern Ghana is subtitled: "A Study in Rural Capitalism." See Wruss, op. cit. supra note 32, at 209.

35. In 1938 the Commission on the Marketing of West African Cocoa reported: "Land has been in great demand. Strangers ... have been willing to pay large sums for land on 
These developments accentuated the proprietary attitudes of stubject-11sufructuaries to the lands they had cultivated and undermined the concept of the stool's dominium of land. As Governor Hugh Clifford pointedly asked as early as $1918:^{36}$

If the land belonged to the tribe, and the fruits which labour wrung from it to the tiller of it, when the occupation by the latter ran into a long period of years, instead of lasting only for a season or so, what became of the communal property in the soil?

The introduction of commercial farming thus meant the indefinite appropriation, by the subject, of a specific portion of state land, which denuded the stool's absolute ownership of its substance because the possibility of reverter to the stool, a frequent occurrence under the old system, became highly unlikely. Further, as we shall see later, the subject's unfettered right to alienate his farm gradually matured into a right to alienate the land itself, subject to formal reference to the stool. The purist might persist in applying the terminology of the classical usufruct to the subjects' enhanced interest, but clearly the traditional scheme of interests in land was rapidly disintegrating.

The improvement in the structure and durability of buildings hastened this disintegration. Concrete and bricks, reinforced by steel and iron installations, replaced, to a large extent, mud and straw as building materials, and the stibject could now look forward to occupying his house indefinitely. 'Thus permanent cultivation was matched by permanent habitation, and the conflict between traditional doctrine and social reality was inevitable. ${ }^{37}$

In fact this conflict was foreseen by the Colonial Administration as early as the 1890's. One of the aims of the abortive Public Lands Bill, 38 introduced by Governor Maxwell in 1897, was to "transmute tribal or family holdings into individual ownership." The bill proposed the institution of a "settler's right" by which the occupant of any vacant stool land might, by permanently occupying and developing it, "acquire a good title as against the chief or any-

which to establish farms. The custodians of tribal, stool and family lands . . . have welcomed the opportunity of easy money." Cmd. 5845. Report of the Commission on the Marketing of West African Cocoa, $\pi$ 58, quoted in MeEk, Land Law and Custom IN tule CoLONIES 174 (1946).

36. CaRdinall, op. cit. supra note 17 , at $57-58$, culled from an article in Blackzood"s, Jan., 1918.

37. Fortes, supra note 29 , at 13 :

Today, as twenty years ago, the fundamental principle that the land itself, the soil or earth belongs inalienably to the stool prevails absolutely. The user of the lant owns only the usufruct. Complications are however beginning to creep into the legal application of these principles owing to the fact that modern forms of 'improvenuent' - cocoa or permanent buildings, for example - create a de facto permanency in the form of the usufruct.

38. The Public Lands Bill sought to declare crown ownership of all tnoccupied lands in the country. The Bill was dropped in the face of fierce opposition by the indigenous peoples who castigated the Bill as confiscatory, invoking the customary doctrine that unoccupied lands were not ownerless, but vested in the stools in whose jurisdiction they were situated. 
one else," a title which, moreover, was to be permanent, heritable and transferrable and which the supreme court of the Colony would enforce. To those who assailed this proposal as repugnant to customary law, the Governor replied that, on the contrary, as matters then stood, a subject could even without the consent of his stool, by continuous cultivation, create a right of occupancy in agricultural or other land which was permanent, heritable and transferrable. ${ }^{39}$ In other words the embryonic idea of "freehold" had already taken root. The opposition to Governor Maxwell's bill prevailed, but the emergence of a new kind of interest was patent enough to attract the specific recommendation of the West African Lands Committee ${ }^{10}$ - militant advocates of "pure native tenure" - that legislation be aimed at "checking the progress of individual tenure and the strengthening of native custom."11 Notwithstanding its attachment to traditional doctrines in their pristine purity, this committee was realistic enough to acknowledge the existence of "individual ownership" and further, to recommend that the vested rights of such individual owners be left intact and placed under a distinct and articulate legal regime permitting virtually all the incidents of freehold in the common law sense.42

39. Maxwell's dispatch to the British Colonial Office, 28th September, 1896, quoted in Branney, Towards the Systematic Individualization of African Land Temure, 11 J. AFr. ADMm. 208, 210 (1959).

40. This Committee was set up in 1912 by the British Colonial Office to consider the laws in force in the British West African colonies and Protectorates, regulating the conditions under which rights over land or the produce thereof might be transferred, and to report whether any and if so what amendments of the law were required. The Committee's work was interrupted by the outbreak of the war in 1914, and no definite report was submitted apart from a draft report issued in 1916 as a confidential document. The tentative recommendations contained in this draft reported were never acted upon in Ghana, but the proceedings threw considerable light on the problems which the impact of new social and economic conditions on traditional customary law posed for the Colonial Administration.

41. The Committee, in fact, advised the promulgation of a statutory declaration:

(1) that it should be presumed that all land of which a native is in beneficial occupation belongs to the family or the community of which he is a member; and (2) that the native occupier of family or community land holds the land on behalf of the whole family or community and has no separate or individual interest in the land, though he has in the crops. He is, therefore, only entitled to sell or mortgage the latter; consequently he has no interest in the land which can validly be taken in execution or sold.

See MFEer, op. cit. supra note 35 , at 183.

42. Some of the suggested incidents of ownership under this regime were that:

(1) The presumption that all land of which a native was in beneficial oceupation belonged to the community or family should not apply, but the contrary presumption should be made.

(2) Individual owners should have the power to lease, sell or dispose by will of their land and it should be liable to seizure in execution for debt.

(3) Assurances should be by simple document in writing.

(4) Upon the death of an individual owner, probate or letters of administration should be requisite to perfect the legal title of the successor. But with regard to the devolution of the beneficial interest in default of testamentary deposition a strict Id. at 184 . adherence to the rules of English law should not be required. 
Contrary to many familiar assertions, outright alienation of land by sale, involving total divestiture of the proprietary interest in land, was not unknown to the traditional legal process. ${ }^{43}$ The institution of guaha, the customary equivalent of conveyance or sale, is not only an authentic indigenous institution but was well-settled in the traditional phase of customary jurisprudence. The ingredients of guaha leave no room for doubt that the transaction contemplates outright alienation. Thus, the ancestral spirits - the "real owners" of the land - have to be placated for the perpetration of that radical dispositive act which obliges them to leave the land. Other forms of transfer which reserved reversionary rights in the grantor did not require the ritual of placating the ancestral spirits, since they fell short of outright alienation. That sale was a legal possibility is sustained by recent research in economic history which has disclosed considerable incidence of land sales in the Densu Valley in the 1860 's, even before the growth of commercial agriculture.44 However, competence to effect alienation by sale was exclusively vested in the stool, and the earliest instances of sales took the form of transfers between stools or communities. ${ }^{45}$

Further, though such sales were possible, traditional beliefs sternly frowned upon them. Alienation of land was unquestionably a rare phenomenon in former days, especially in Ashanti. Land was the most valuable asset in traditional society, and the source and symbol of political power. In the felicitous words of Danquah:

An absolute sale of land was therefore not simply a question of alienating realty; notoriously it was a case of selling a spiritual heritage for a mess of pottage, a veritable betrayal of ancestral trust, an undoing of posterity. ${ }^{40}$

Thus the usual dealing in land was a transfer which did not foreclose the possibility of reverter to the grantor. ${ }^{47}$

Two important developments in this century radically changed traditional attitudes to alienation: the growth of commercial activities involving land, and the reception of English juristic ideas.

Towards the end of the nineteenth century, mining possibilities in Ghana attracted European attention. The successive waves of concession hunters

43. Sir William Brandford Griffth, C.J., testified before the West African Lands Committee as follows:

From my judicial experience in land cases I should have no hesitation in saying that in ancient times land could be sold. . . . The idea of sale of land as between natives was so very definite and was so taken for granted, I have never had occasion to consider the question.

Hrin, op. cit. supra note 39 , at 138 n.4.

44. See HIII, op. cit. supra note 39 , at 240 .

45. Id. at 139.

46. Also see Danguah, Aran Laws and Customs 212 (1928).

47. Sarbah, Fanti Customary Laws 86 (2d ed. 1904):

Rather than sell his land, the Fanti prefers to grant leave to another, a friend or alien to cultivate or dwell upon it for an indefinite time, thus reserving unto himself the reversion and the right to resume possession whenever he pleases. 
for mining interests in gold, manganese, iron, and diamonds managed to persuade the traditional authorities to overcome their scruples against the alienation of land. Mining concerns obtained for little consideration rights of far reaching consequence over vast areas of Ghanaian land. ${ }^{48}$ Far from the right of occupancy usually given to strangers or the interests of a customary abunu or abusa tenant, ${ }^{49}$ these mining concessionaires were granted, in the form of long-term leases, unprecedented powers of exploitation practically amounting to transfer of ownership.

The mining boom of the late nineteenth century resulted in alienation of vast expanses of land. A new land market emerged and the prospect of ready cash began to erode the fabric of religious and other restraints upon alienation of land. Similar consequences followed the introduction of commercial agriculture. In the 1890's great numbers of cocoa farmers migrated from the congested areas in southeastern Ghana to more spacious lands, and purchased extensive tracts of land from the various stools. ${ }^{50}$ These sales were absolute and attempted to transfer rights in land without conditions. ${ }^{.1}$

The impact of frequent and extensive alienation to individual strangers on the traditional schema was significant: The quantum of the interest which passed under such alienation, whether it be concession or sale, was considerably more substantial than the classical usufruct which traditional law accorded to the individual. Though a stranger-purchaser still formally acknowledged the stool's allodial title, he was absolute owner of the land in the proprietary sense. He had a full unencumbered title to the land which was transmissible and alienable without reference to any authority. He was not obliged to render any services to the grantor-stool after payment of the purchase price,

48. By 1900, 25,508 square miles of Ghanaian land were burdened with such concessions, one-sixth of the whole country. 3 HaIley, Native Adarnistratio:z in Britisi AFrICAN TERRITORIES 221 (1951).

49. Under an abusa tenancy, the owner or usufructuary holder of a tract of uncultivated land grants exclusive possession and the beneficial enjoyment thereof to another in consideration of that other cultivating the land with his (the tenant's) own resources and surrendering a third share of the profits accruing from the land to the landlord.

50. See HIII, op. cit. supra note 39, at 138-49.

51. Id. at 141. Indeed the Paramount Stool of Akim-Abuakwa was so alarmed at the practice of extensive alienation by lesser stools that it promulgated by laws: "to prevent the vulgar and undue alienation of Eastern Akim Stool lands hitherto conserved." AkimAbuakwa Bylaws, Dec. 24, 1913. Id. at 148.

Although the new economic opportunities made land a valuable economic asset, they' also involved stools, families and sometimes individuals in expensive and protracted litigation for the purposes of establishing their title to land. This luxury often brought financial ruin to the parties, which again compelled them to sell their lands to defray legal expenses, or to mortgage their lands as security for loans for these purposes. See the Report of the Havers Commission appointed by the Gold Coast Governor in 1944 to investigate "the expenses incurred in the Courts of the Gold Coast and indebtedness caused thercby," quoted in Busia, op. cit. stipra note 19, at 206-07. Indebtedness and sale of land were so closely linked that the view once prevailed that the existence of a stool-debt was a necessary precondition to alienation of stool land. See Golightly v. Ashrifi, 14 W. Afr. Ct. App. 676 (1955) (View of Jackson, J., in the court below, disapproved on appeal). 
nor were his rights of beneficial user restricted in any manner. So complete was his ownership that his own stool was often emboldened to challenge the suzerainty of the grantor-stool over the land so alienated. ${ }^{62}$ The Ghanaian "freehold" had arrived.

The idea that an individual was capable of holding an interest ranking as a species of ownership had a profound effect on the attitudes of stool subjects who were still technically usufructuaries. They saw no reason why the status of a stranger's interest should be superior to theirs. What strangers acquired with valuable consideration, stool subjects claimed by birthright. The latter therefore developed a more assertive proprietary attitude to stool land in their occupation, especially where they had established a regime of permanent cultivation. In any case, whether by design or by accident of professional incompetence, Ghanaian conveyancers drew no distinction between the interest of stool subjects and those of stranger-purchasers. Dispositions by both categories of holders were characterized as transfers "in fee simple free from all encumbrances."

As alienation of land became an established and familiar practice, the traditional impediments to outright alienation by subjects began to lose their vitality. The trappings of doctrine were observed by obtaining the stool's consent before alienation. This meant the recognition of a limited competence on the part of the subject, but soon the requirement as to prior consent was to degenerate into an obligation to pay a prescribed fee to the stool in lieu of such consent. The area of the subject's competence has markedly increased, and the requirement as to prior reference to the stool is now regarded as merely of evidentiary significance, and in no way constituting a stbstantive bar to sale by the subject.

About the same time as these economic changes were occurring, Ghana "received" the common law. This reception did not result in the proscription of the customary law of property. A pluralistic legal system was established under which various matters were assigned to either English law or customary law. But the "saving" of the customary law did not prevent the adoption of English conveyancing forms and techniques in the transfer of customary interests in land. ${ }^{\text {B3 }}$ Because European merchants desirous of acquiring land for various purposes always insisted upon assurances by deed in place of the indigenous verbal forms, reducing land transactions into writing soon became the established usage throughout the country. ${ }^{54}$ Two types of

52. See HInL, op. cit. supra note 39, at 146. Thus the Paramount Chicf of Akwapim occasionally claimed jurisdicional rights over the Akim-Abuakwa lands bought and inthabited by Akwapim farmers.

53. Section 19 of the Courts Ordinance, 1876, as reënacted, 1 LAws of THE GoLd COAST c. 4 (1937) which granted a general imperial dispensation for the application of native law "in causes and matters where the parties are natives," specifically mentioncd causes and matters relating to the tenure and transfer of real and personal property as falling within the province of customary law.

54. Redwar observes that these conveyances by deed were particularly useful to European merchants "when wishing to take security over the lands of their native agents to 
documents developed: those which were merely memoranda of dispositions in customary form, and therefore had a purely evidentiary status; and those which constituted the dispositive acts themselves. The latter were usually drafted by English-trained lawyers who relied heavily on English conveyancing precedents. Since the institution of usufruct is unknown to English land law, the forms adopted for Ghanaian purposes invariably paraded the terminology and incidents of the common law freehold. Not unnaturally, usufructuaries increasingly thought of themselves as enjoying interests distinctly superior to mere rights of beneficial user. ${ }^{\text {t5 }}$

It is often hazardous to attribute particular developments in the African social process to the somewhat nebulous phenomenon of "Western ideas." But any discussion of the evolution of the concept of an "estate" or "freehold" in Ghana would be incomplete without mention of the influence of English juristic and social ideas, which were dominated by a strong tradition of individualism in the early years of British rule in Ghana. The official policy of the Colonial Administration towards individualization of landed interests was uncertain. Governor Maxwell, for example, declared for robust individualism, ${ }^{56}$ whereas the West African Lands Committee strongly advocated a reversion to "communal tenure." But the flow of ideas between peoples need not be channelled through official avenues. Ghanaian lawyers were Britishtrained, as were the rest of the elite. Notions of individual ownership were part of the new order of things, and although nothing has entirely succeeded in disrupting the fabric of Ghanaian collectivist social organization and attitudes, the pull in other directions has been manifest since the turn of the century.

The disintegration of the traditional scheme of interests in land was aided in no small measure by the decline of traditional political authority. As we have seen, the customary services exigible from subjects were really incidents of political allegiance, ${ }^{57}$ nevertheless some services were so identified with the subject's user of land that they came to be looked upon as indicia of the stool's dominium. Modern times have, however, witnessed the falling of these

secure the proper accounting for the money in the agents' hands." ReDwan, Coxnmesis oN SOARE ORDINANCES OF THE GOLD COAST COLONY 75 (1909). Nor was this practice confined to dispositions in favor of Europeans. As early as 1909 Redwar noted "Even as amongst natives there has grown up a practice in the larger towns on the coastline of evidencing the transfer of land by deed or writing. ..." Id. at 76.

55. In 1939 the Annual Report of the Social and Econoanc Progress of tale People of THE Gold COAST (1938-39) reported that the "Gold Coast farmer was so landconscious that it was becoming the rule rather than the exception that he should obtain his farm by way of absolute grant evidenced by a wriften document." Summarized in MEEK, op. cit. supra note 35 , at 171 n.4.

56. The Governor advocated a personal proprietorship of land free from the operation of native laws and customs "which often makes lands practically inalienable by the recognition of the right of every member of a family to an undivided share in the property:" Maxwell to C.O., Sept. 28, 1896, cited in Branney, Tou'ards the Systenalic Indiziditalisation of African Land Tenure, 11 J. AFr. Adarn. 208, 210 n.10 (1959).

57. See text accompanying note $\mathbf{3 0}$ supra. 
services into desuetude. With the commercialization of agriculture, chiefs experienced considerable difficulty in enforcing the performance of the services. The advent of new economic opportunities in the urban areas attracted considerable movement of population from the agricultural areas. Subjects basking in the self-sufficiency of commercial farming showed little inclination to be servile to the Chief, while other subjects were simply inaccessible by reason of their new occupation in distant lands.58 With the lapse of these services, some of the most tangible indicia of the stool's dominium came to an end, and the subject's interest in stool land was practically unencumbered. Nor did existence of British authority strengthen the Chief's position. Despite the administration's efforts to bolster up traditional institutions through the system of indirect rule, the presence of the superior British jurisdiction undermined allegiance to traditional authority. ${ }^{69}$

\section{The Courts and the New Developments}

Judicial attitudes to the impact of these economic and social changes on the traditional holdings passed through three phases. In the first phase - a brief one - realism prevailed. The court's opinions recognized the new social phenomena, and the traditional categories were overtly challenged in the light of changing conditions. This phase was followed by a long spell in which the superior courts, ${ }^{60}$ alarmed at the pace of the erosion of the traditional schema,

58. RATTRAY, op. cit. supra note 11 , at 365 :

Subjects, whether lesser Stools, heads of families or individuals among whom all this land had been distributed in the past, have now for some time been enjoying their tenancies relieved of their most onerous obligations. One and all are gradually coming to regard the land as their own, in a sense that the freeholder in England would regard his tenure in fee simple. They will, in time, if this has not already occurred, come to claim the unrestricted right to mortgage, sell and devise.

59. See Busia, op. cit. supra note 19, at 198.

60. A brief outline of Ghanaian court structure may be helpful: By the Supreme Court Ordinance, 1876, as amended, 1 Laws of Gold CoAst c. 7 (1920), the Supreme Court of Judicature was created for the Gold Coast Colony "and for territories thereto near and adjacent wherein Her Majesty may at any time before or after the commencement of this Ordinance have acquired powers and jurisdiction." Id. at $\$ 12$. The Court comprised the Full Court - the appellate tribunal - and divisional courts sitting in each of the administrative provinces of the colony. Appeals from the Full Court lay to the Privy Council. In 1928, the West African Court of Appeal was established as the penultimate Court of Appeal for British dependencies in West Africa, with jurisdiction to entertain appeals from the Supreme Courts of Gambia, Gold Coast, Nigeria and Sierra Leone. 1 Laws of Gouv CoAst c. 5 (1937), as amended. The Gold Coast judiciary was reorganized by extending the Supreme Court Ordinance of 1876 to the later accretions to the British jurisdiction, namely, Ashanti and the Northern Territories, thereby creating one Supreme Court for the whole colony. Thus immediately prior to independence (March 6, 1957) the highest tribunal situated in the Gold Coast was the Supreme Court from which appeals lay to the West African Court of Appeal and thence to the Privy Council.

The Courts (Amendment) Ordinance, 1957, created the High Court and the Court of Appeal as component parts of the Supreme Court, and abolished the right of appeal to the W. Afr. Ct. App., whose appellate jurisdiction was transferred to the new Court of Appeal. However, the Privy Council retained its ultimate appellate jurisdiction. Ghana (Appeal to 
reverted to "pure native law." The old conceptions of usufruct and "communal ownership" were emphatically restated and applied with scant regard for the social realities. Finally, in the present phase, courts, while paying lip service to the traditional scheme, seem to be giving judicial effect to the changing conditions. Traditional terminology is piously invoked though the legal consequences which the courts attach to the conceptual scheme represent a radical departure from the old order.

"The moving spirit behind the "realist" movement was Chief Justice Brandford Griffith, whose opinions dominated the superior courts in the first quarter of.this century. The rationale of his judgments and those following his decisions, was that the new phenomenon of permanent cultivation and occupation had transformed the subject's usufruct in stool land into a species of ownership, hardly distinguishable from the English freehold. The locus classicus of this thesis was Lokko v. Konklofi. ${ }^{61}$. Konklofi held, as his father's successor, usufructuary rights to a tract of stool land, on which he erected a cottage and undertook commercial farming. Konklofi subsequently "pledged" this land as security for a loan "without the prior consent of the stool. Upon Konklof's default, the creditor sought to attach the land. At this juncture, a claimant interpleaded on behalf of the stool on the ground that the land was stool property and therefore could not be seized in satisfaction of the private debt of a subjectusufructuary. To determine that Konklofi had an attachable interest in stool land, the court was not compelled to rule that he had the equivalent of freehold interest, since a usufruct, even under the traditional scheme was substantial enough for the purposes of attachment. Usufructuary rights were, after all, concrete property rights, encompassing, for example, the absolute interest in a farm or a building. Sir Brandford Griffith indeed held that Konklof had perfected an attachable usufructuary interest..02 But he went further and ruled that permanent cultivation gave rise to a landed interest markedly superior

Privy Council) Order in Council, 1957, Laws of Grana 387 (1957). The Republican Constitution (July 1, 1960) again reorganized the Ghana Judiciary. There are now two superior courts, the High Court and the Supreme Court. The right of appeal to the Privy Council was abolished by the Constitution (consequential provisions) Act, 1960, (LA 8). The Supreme Court is now the Court of last resort in Ghana. Article 42(4) of the Republican Constitution reads:

The Supreme Court shall in principle be bound to follow its own previous decisions on questions of law, and the High Court shall be bound to follow the previous decisions of the Supreme Court on sugch quèstions, but neither Court shall be otherwise bound to follow the previous decisions of any court in questions of law.

61. [1907] Ren, 450.

62. .... it is notorious that as long as the stool-subject continues to live on or to work land, so long is he entitled to live on and to work that land. Furthermore, the evidence shows that Konklofi is entitled to use his village and farms; as long as he likes he can live in his village, cut his sugar canes and pluck his cocos, and the stool holder cannot disturb him. He has therefore, even assuming the land to be stool land and not his property, a valuable interest in this land. I see no reason why this interest or property should not be seized and sold in execution.

Id. at 452-53. 
to the rights of beneficial user envisaged by the traditional usufruct. The Chief Justice supported this distinction by an empirical examination of the new economic order. He pointed out that while Konklofi gave part of the produce of his subsistence farms to the stool, as was customarily required in respect of a usufruct, he performed no such services in respect to the land under permanent cultivation. Furthermore, the stool tacitly acknowledged the validity of the pledge when it urged Konklofi to pay the judgment debt in order "to save the land." 63 In effect, Konklofi's interest was equivalent to a freehold, fully alienable subject only to a formal requirement of prior consultation with the stool. Breach of this requirement did not render the alienation void but merely improper. There was accordingly no basis for the stool's interpleader.

The Chief Justice spelt out his thesis as follows:

In the present case there has been continuous occupation for about 40 years and the occupier has been permitted to build a village on the land and to make permanent farms. The present is like thousands of similar cases. Stool land has been settled by a father, the son has succeeded, has built a village and has made a home on the land. There has been no express alienation by the stool but there has been recognition of exclusive occupation. .... [Konklofi has] appropriated that portion of the stool land to himself with the tacit consent of the stool, and [it is] no longer stool property, but his own property.

Whether the stool has impliedly consented to Konklofi appropriating the land as his own or whether the view be taken that the stool is now estopped from putting forward its claim to the land does not matter, but $I$ am of opinion that the occupation has been of such continuance and of such a character that the land must be now deemed to be the property of Konklofi and seizable in execution. ${ }^{84}$

This was indeed a startling decision. The bold assertion that a subject could acquire exclusive ownership of stool land, through some sort of prescriptive occupation, violently offended the fundamental traditional principle that the stool could never be divested of its dominium of stool land by reason only of the subject's long possession. Not surprisingly, the West African Lands Committee severely criticized the case on the grounds that the Chief Justice had improperly applied English principles of prescription to the Ghanaian situation, and that the holding in the case spelt the ultimate conversion of all stool land into private land. ${ }^{65}$ Nevertheless, the Lokko doctrine won some notable converts in the courts. In Sam v. Tham ${ }^{60}$ Justice Michelin, relying on

63. It was not shifting farm land that he had pledged but land which he had occupied for many years, and which his father had occupied before him, land upon which he had built a village and upon which he had permanent cultivation; knowing all this they [the stool and the claimant] felt that however wrong Konklofi had been to pledge the land without letting them, nevertheless the pledge was valid.

Id. at 453 .

64. Id. at 453-54.

65. See MEer, op. cit. supra note 35 , at 182 . The Lokko case prompted the committce to recommend the promulgation of a statute declaring that the subject had no individual interest in stool land which could be validly sold or attached in execution.

66. [1924] Sel. J. Div. Ct. Gold Coast '21-'25 (D. Ct.) 63. 
the Lokko case, held that the cultivation of stool land for twenty years sufficed to invest the subject with a proprietary interest upon which he could ground an interpleader against the attachment of such land in satisfaction of the stool's debt or the debt of any third party. In Kodadja v. Tekpo ${ }^{\text {or }}$ the court again applied the Lokko prescription doctrine and found for the cultivator of the land as against a creditor of the stool..$^{68}$ The subject's permanent and exclusive occupation, typical of commercial farming, provided the ground for upholding his claim that the lands were. "not stool lands but private property."

An interesting case which, at first blush, appears to be at variance with the Lokko doctrine is Owusu $v$. Manche of Labadi, ${ }^{\mathrm{co}}$ one of the earliest decisions of the.West African Court of Appeal. In this case, the Labadi stool claimed compensation in respect of the compulsory acquisition, by the Central Government, of certain lands in the Labadi Division, on the grounds that the lands were stool property. Certain subjects of the stool, the Nkwantanang family, challenged the stool's right to the compensation, contending that the lands in question had become their private property by reason of uninterrupted occupation and user for four generations. The stool contended that the subjects had acquired mere usufructuary rights which did not derogate from the stool's dominium, and while the usufructuaries were entitled to a share of the compensation "upon its distribution in accordance with native custom," the stool was the proper authority to receive the compensation. The West African Court of Appeal upheld the stool's claim; long possession by stool-subjects, it ruled, could not found a title adverse to the stool.

Though the court was clearly right in declaring the concept of prescription to be foreign to the classical notions of the proprietary relationships between the stool and its subject, its ruling may be regarded as regressive in as much as it relegated the subject's landed interest to the status of mere rights of beneficial user. The Ownsu case, however, lacked some of those vital elements which led Sir Brandford Griffth and his followers to propound a robust theory of private ownership. The Nkwatanangs had not established any form of permanent cultivation on the lands in question, as had the occupants in the previous cases. They: farmed intermittently by shifting cultivation in circumstances which left the very basis of their claim to possession in some doubt.70 Further-

67. ' [1931] Sel. J. Div. Ct. Gold Coast'29-'31 (C. Ct.) 45.

68. And I am of opinion further that even if it was stool land given to him by his father, his possession, continued over a period exceeding 30 years during which he

... has had the undisturbed and exclusive possession of the land and has made it into a valuable cocoa farm, has now ripened into ownership of the land.

Id. at 47 .

69. 1 W. Afr. Ct. App. 278 (1933).

70. Thus the Court resolved this doubt in the subject's favor, but the evidence was pretty slim:

The native system of farming by shifting cultivation is well known and was amply proved in this case. It is not disputed that the Nhwantanang people have cultivated patches at their will over an area embracing the plots acquired, though no definite limits were set to such area. I think therefore, that they must be said to be construe- 
more, the character of the alienation in this case, sale to the Colonial Government under a compulsory purchase order, was radically different from the alienations in the previous cases. Compulsory acquisition by the Colonial Government resulted in the complete determination of all proprietary and jurisdictional rights, claims, titles or other interests vested in the stool or any other person. In other words, it utterly foreclosed the remotest possibility of reverter to the stool, which meant the complete divestiture of the stool's dominium and dominion. The conversion of stool land into crown land was therefore peculiarly cognizable by the stool, and there thus would appear to be some justification for the assertion of the stool's exclusive competence to convey, and in consequence, its right to receive the compensation in respect of such acquisition - subject, of course, to paying an appropriate portion to the subject usufructuary.

The "realist" movement in the courts suffered a setback in the late 1920's, beginning with the Privy Council decision of Amodu Tijani v. Socretary, Southern Nigeria. ${ }^{71}$ Lord Haldane, in delivering the opinion of the Judicial Committee, made major pronouncements, not only on West African land law, but on "the various systems of native jurisprudence throughout the empire." He also definitively endorsed Chief Justice Rayner's report on West African land tenure, the heart of which read:

The next fact which it is important to bear in mind in order to understand the native land law is that the notion of individual ownership is quite foreign to native ideas. Land belongs to the community, the village or the family, never to the individual. All the members of the community, village or family have equal right to the land, but in every case the Chief or Headman of the community or village, or head of the family, has charge of the land, and in loose mode of speech is sometimes called the owner. $\mathrm{He}$ is to some extent in the position of a trustee, and as such holds the land for the use of the community or family. He has control of it and any member who wants a piece of it to cultivate or build a house upon, goes to him for it. But the land so given still remains the property of the community or family. He cannot make any important disposition of the land without consulting the elders of the community or family, and their consent must in all cases be given before a grant can be made to a stranger. ${ }^{72}$

It need hardly be stressed that this formulation had no universal validity in respect of the indigenous land law in West Africa. True, the proposition that an individual could not own land was unimpeachable with reference to the location of dominium or absolute ownership in the highly centralized states. But the report is deceptive in that it omits the fact that individuals could hold substantial and exclusive property rights in the form of the traditional usti-

tively in occupation of the whole area upon which native custom recognizes they are entitled to farm, and over which they have been farming for generations. Id. at 281 .

71. [1921] 2 A.C. 399.

72. Id. at 404-05. 
fruct. The concept of the stool's dominium did not foreclose exclusive possession in an individual, and the Anglo-American idea of unity of possession was only applicable to waste lands to which the community resorted for fodder and other domestic items. As far as the position in the less centralized states and societies was concerned, there was no doctrinal prohibition of individual, absolute ownership; the stool's suzerainty did not carry dominium. Although corporate ownership was the predominant feature of property holdings there, individual ownership was equally admissible, albeit rare. When Rayner's report was prepared in 1898, individual economic resources were not substantial enough to sustain that type of private enterprise conducive to the creation of a regime of individual ownership or individual usufruct. Nonetheless, Rayner himself recognized the emergence of individual ownership even in his own time, though he oversimplified factors contributing to the growth of this phenomenon by attributing it entirely to the intrusion of English ideas. A tacit jurisprudential premise of this recognition is the idea that customary law is capable of changing in response to new conditions - an idea which appears to have escaped so many of Rayner's successors.

In elaborating upon Rayner's thesis, Lord Haldane deplored the tendency "operating at times unconsciously, to render [native] title [to land] conceptually in terms appropriate only to systems which have grown up under English law," and then proceeded to announce his classic definition of the usufruct:

A very usual form of native title is that of a usufructuary right, which is a mere qualification of or burden on the radical or final title of the Sovereign where that exists. In such cases the title of the Sovereign is a pure legal estate, to which beneficial rights may or may not be attached. But this estate is qualified by a right of beneficial user which may not assume definite forms analogous to estates, or may, where it has assumed these, have derived them from the intrusion of the mere analogy of English jurisprudence. ${ }^{73}$

This was a resounding restatement of the traditional usufruct - an interest assuring indefinite rights of beneficial user but falling short of ownership. However, even Lord Haldane did not rule out the possibility of change in the traditional scheme of interests. Indeed, he advocated a pragmatic approach in the ascertainment of the state of the law in particular communities at various times:

In India, as in Southern Nigeria, there is yet another feature of the fundamental nature of the title to land which must be borne in mind. The title, such as it is, may not be that of the individual, as in this country it nearly always is in some form, but may be that of a community. Such a community may have the possessory title to the common enjoyment of a usufruct, with customs under which its individual members are admitted to enjoyment, and even to a right of transmitting the individual enjoyment as members by assignment inter vivos or by succession. To ascertain how far this latter development of right has progressed involves

73. Id. at 403 . 
the study of the history of the particular community and its usages in each case. Abstract principles fashioned a priori are of but little assistance. and are often as not misleading. ${ }^{74}$

Lord Haldane's advice, however, was not heeded. Subsequent coturts invoked Rayner's formulation as an immutable postulate, applied without reference to contemporary social reality. ${ }^{75}$ For example, the West African Court of Appeal, in affirming a holding below that a community cotild compel an individual who had collected rents on land to disgorge those rents because the land was communally held, cited Rayner's formulation with reverent approval, and summed up the prevailing judicial attitude to Rayner as follows :

There can be no quarrel with that statement of customary tenure. As a general principle it has been applied in numerous cases and in postulating, as the learned judge did, that land belongs to the community and then, in deciding on the evidence in this case, that it belonged to the Nze community, he was not departing from the principles of native customary tenure. ${ }^{76}$

This declaration demonstrates the tenacity with which the Superior Courts of West Africa clung to the concept of communal ownership of land as the first postulate of customary land law, notwithstanding the momentous economic and social changes which occurred within the fifty-odd years following Rayner's report. Further, it discloses the essentially a priori approach of the courts; a judge first proceeds by postulating that land belongs to the community and then applies the postulate to the case before him.

This reversion to "pure native tenure" was well documented in Ghanaian cases. In Kuma v. Kuma ${ }^{77}$ the Chief of Abrobonku sued the defendant, a stranger, for a declaration that a parcel of land lying near Abrobonku was part of his stool lands. The defendant resisted on the ground of prior occupation by his ancestors, asserting that he and his ancestors "had been in occupation of the land in suit for six generations without let or hindrance by the plaintiff or his ancestors, that they have never paid tribute, performed acts of fealty, or given drink to the plaintiff for permission to farm." The Chief countered that waiver of tribute did not imply recognition of the defendants' ownership; the defendants' ancestors had merely been granted strangers' rights of bene-

74. Id. at 403-04 (emphasis supplied).

75. E.g., in Summom v. Dist Raphael, the Privy Council reaffirmed Rayner's statement, observing:

Their Lordships are aware that it is possible by special conveyancing to confer title on individuals in West Africa, but it is a practice which is not to be prestuned to have been applied, and the presumption is strongly against it. Prima facie the title is the usufructuary title of the family, and whoever may be in possession of tho legal title holds it with that qualification.

[1927] A.C. 881, 883-84.

Rayner's formulation was applied also in Hammond v. Randolph, W. Afr. Ct. App. 42 (1936), a Ghana case, and in Stool of Abinabina v. Enyimadı, 12 W. Afr. Ct. App. 171 (1953), also a Ghana case.

76. Eze v. Igiliegbe, 14 W. Afr. Ct. App. 61, 62 (1952).

77. 5 W. Afr. Ct. App. 4, 7 (1938). 
ficial user by his predecessors, and although the Chief had followed the "practice of his forbears in not exacting tribute from persons occupying the land," he had always resisted any attempt by the defendant to dispose of the land. The Privy Council upheld the Chief's claim, rejecting the concept of adverse possession as foreign " to customary law. ${ }^{78}$

This case did not present the stool-subject situation to which the Tijani doctrine is particularly relevant. Rights of beneficial user granted to strangers under an indefinite license could not found a title adverse to that of stoolgrantor; and the Privy Council's holding in the Chief's favor would have been unexceptionable if it had not gone out of its way to invoke the Tijani doctrine in terms which appeared absolutely to foreclose the evolution of individual ownership. The rejection of the concept of adverse possession need not preclude the recognition of the evolution of an enhanced interest of the subject amounting to a species of ownership and coexisting with the stool's dominium.

The traditional schema were reasserted in the recent case of Golightly $v$. Ashrifi. ${ }^{79}$ One of the many complex issues at bar centered on the quantum of the interest of the Atukpai subjects in Gbese stool lands, which they had cultivated and occupied for over fifty years. The Atukpais claimed rights of ownership over such lands, including the right to alienate them, on the basis of their occupation and also their overt exercise of such rights of ownership as the right to sell without "let or hindrance by any stool." The trial judge, Jackson, J., had rejected these claims on the ground that they were merely entitled to rights of beneficial user which would revert to the stool if farming ceased.80

.In the appeal of this case Foster-Sutton, the President of the West African Court of Appeal, followed the usual a priori pattern :

Before proceeding further it may be as well to set out the character of the land tenure applicable, for the main relevant findings of the learned trial Judge are ... in accord with it.

In Amodu Tijani v. Secretary, Southern Nigeria, the Privy Council set out the opinion of Rayner, C. J., in a Report on Land Tenure in West Africa as substantially the true one . . . . ${ }^{81}$

His Lordship then cited the familiar formulation, and in the light of that invocation he approved the trial judge's definition of the rights of the Atukpais. Frozen in its formula of land tenure, the Appeal Court attributed the "unwarrantable conduct" of the Atukpais in exercising rights of ownership, includ-

78. It appears, therefore, that among the natives, occupation of land is frequently allowed for the purpose of cultivation but without the ownership being parted with. The owner of the land being willing to allow such occupation so long as no adverse claim is made by the occupier; the occupier knowing that he can use the land as long as he likes provided he recognizes the title of the owner.

Id. at $8-9$.

79. 14 W. Afr. Ct. App. 676, 680-81 (1955).

80. Id. at 678-79.

81. Id. at 680 (footnote omitted). 
ing outright sale of the land, to the dissension among the various stool owners of the land ${ }^{82}$ rather than the general change in methods of tenure throughout Ghana, and thus upheld a strict traditional conception of the subjects' usufruct. Although the facts do not disclose the type of farming practiced by the Atukpais on the lands, it is clear that they had built villages and were in permanent occupation.

Justice Jackson, the trial judge, was so wedded to the traditional order that he even proclaimed that a stool was incapable of selling stool land except for the limited purpose of defraying its debts. On this point, however, the Appeal Court chose the path of realism, and overruled the trial judge in emphatic terms:

As Webber, J., observed ... in Brimah Balogun and others v. Saka Chief Oshodi... "The chief characteristic feature of native law is its flexibility - one incident of land tenure after another disappears as the times change - but the most important incident of tenure which has crept in and become firmly established as a rule of native law is alienation of land".

In our opinion the existence of a stool debt was not at the times material to this inquiry a necessary preliminary condition to the sale of stool land. ${ }^{80}$

It is curious that the Court should have been impressed with the flexibility of customary law on one issue while adopting a rigid approach to another.

The modern trend in judicial attitudes is to forge a bond between realism and traditional forms. The courts in effect acknowledge and enforce the substantial changes in traditional land law which were evident even in the dnys of Sir Brandford Griffith, but they have not jettisoned traditional terminology. The concept of the stool's absolute ownership and its corollary of the subjects' usufruct still appear in the judgments, but the legal consequences of these concepts have been greatly diminished.

A convenient introduction to this development is Mr. Justice Ollennu's dictum in Ohimen v. Adjei: ${ }^{84}$

The stool holds the absolute title in the land as trustee for and on behalf of its subjects, and the subjects are entitled to the beneficial interest or usufruct thereof and have to serve the stool. Each individual or family is regarded in the broad sense as the owner of so much of the land as it is able by its industry or by the industry of its ancestors to reduce into possession and control. The area of land so reduced into the lawful possession of the individual or family, and over which he or they exercise a usufructuary right, is usually called his property. It cannot, save with

82. Id. at 683 .

83. Id. at 681 .

The Appellate Tribunal's endorsement of Jackson's formulation of a subject's interest in stool land had an interesting, though unsuspected, result. The Atukpais, who had claimed an enhanced interest in stool lands, were represented by Mr. Ollennu, later to become a High Court Judge and a Supreme Court Judge successively. Mr. Justice Ollennu's basic attitude to the customary scheme of interests stems from his sharp reaction to Jackson's formulation. It may be said that current judicial trends are dominated by the learned Judge's sustained repudiation of Jackson's definition of the subjects' interest in stool land.

84. 2 W. Afr. L. Rep. $275,279-80$ (1957). 
the express consent of the family or individual, be disposed of by the stool. The individual or family may assign or dispose of his interest in the land to another subject of the stool and the land may be sold in execution of a decree against the individual, or the family as the case may be, without the consent of the stool. But he may not dispose of the stool's absolute ownership in it to strangers without the consent and concurrence of the stool.

Ollennu here describes the subjects' interest as a usufructuary right, but the citation contains significant pointers to the "estate idea." The usufructuary is regarded as "owner" of the area of land reduced into his possession; he can alienate it voluntarily to a fellow-subject or involuntarily to a judgmentcreditor without the stool's consent. Nor can the stool divest the usufructuary of his interest by alienating it to another. Even the absolute prohibition of sale to a stranger is qualified to make such a sale valid if effected with the consent of the stool. We shall see that subsequent cases further subjected this prohibition to the "disintegrating erosion of particular exceptions."

In his work on Ghanaian customary land law, Ollennu emphatically rejects the idea that a subject's interest in stool land consists of a "mere farming and occupation right."

[T] his view of the customary law reduces the subject from his inherent exalted rank to the level of a stranger. Of course it goes without saying that a subject who is compellable to lay down his life for the protection of the land should be entitled to the enjoyment of an estate in that land, superior in essence to the interest which a stranger who has not been accorded the rights of a subject, may acquire in that land. ${ }^{85}$

The linking of a subject's superior interest in stool land with his onerous civic and political obligations is an ingenious piece of ex post facto rationalization. The learned Justice merely uses language appropriate to a traditional context to justify the recognition of the contemporary reality of the subjects enhanced interest. The notion that a subject had partial dominium of land was not a necessary consequence of his civic status in the traditional era; there was ample recognition of his privileged status in his inherent right to cultivate or occupy any unappropriated portion of stool land without prior reference to the stool and without valuable consideration therefor, a right denied to the stranger. Nevertheless the value of Ollennu's thesis does not so much lie in his line of reasoning as in his concern to recognize social reality.

Since the subject's interest is still designated as a usufruct, it becomes pertinent to consider to what extent the new concept retains the characteristics of its traditional signification. In Yiboe v. Duedu, ${ }^{80}$ Ollennu ruled that the subject's usufruct does not oust, but coexists with, the stool's absolute interest in stool land. The new conception of the usufruct therefore avoids the doctrinal difficulties posed by Sir Brandford Griffith's bold assertion that the subject can, by permanent occupation or otherwise, completely divest the stool of the

85. OLLENNU, op. cit. stipra note 8, at 11 .

86. 2 W. Afr. L. Rep. 293 (1957). 
ownership of a portion of stool land. However, if it be accepted that the subject's usufruct is a species of ownership or an estate, then current developments clearly represent a departure from the traditional idea of indivisibility of ownership. The stool, in effect, no longer has dominium of stool land but only an interest in stool land conceptually superior to the subject's. A concept of a split ownership is emerging allowing the existence of separate but simultaneous estates in the same land. This phenomenon is nothing like "the wonderful calculus of estates" of the common law, for the subject's usufruct, which is now comparable to the common law fee simple, does not admit of being broken up. Nevertheless the former attribution of ownership exclusively to the political sovereign no longer obtains.

One of the cardinal incidents of the new usufruct, emphatically underlined by a string of decisions, ${ }^{87}$ is its immunity from divestiture by the stool. Traditional law guaranteed the usufruct against alienation by the stool to another subject without the usufructuary's consent, but modern decisions go considerably further. They have proclaimed the inviolability of the usufruct even where the stool seeks to acquire it for a public cause. In Ohimen v. Adjei ${ }^{88}$ the court upset such an acquisition, declaring:

Where, as in this case, land is required for development which will be beneficial to both the stool and the community generally, co-operation between the stool and the family to be dispossessed is the best method of approach, not high-handed action.

This notion of total inviolability undoubtedly invests the usufruct with a quality unknown in traditional law. In former days, dispossession of the subject was indeed rare, but the stool's right to do so in the public interest, without the subject's consent and without indemnification was an unquestionable attribute of the stool's dominium. In establishing the total inviolability of the subjects' interests, the courts have undoubtedly been influenced by the implication of the new political structuring, which, in effect, reduces stools to subjects in the new state of Ghana. The Central Government claims an "eminent domain"89 which empowers it to acquire citizens' lands for public project. To confer similar powers on stools would not only expose the Ghanaian's land to a "double jeopardy" but also inflate the attenuated authority of the stools.

Two recent cases ${ }^{90}$ have re-emphasized the inviolability of the subject's usufruct by refusing to allow stools to appropriate subjects' interests in agricultural land when that land became part of a growing urban area. The courts held that such appropriation was not customary and even if it were customary,

87. Ohimen v. Adjei, 2 W. Afr. L. Rep. 275-79 (1957); Baidoo v. Osci, 3 W. Afr. L. Rep. 289, 291 (1957); Bruce v. Quarnor, [1959] Ghana L. Rep. 292, 297.

88. 2 W. Afr. L. Rep. 275, 281 (1957). Compensation had in fact been paid by the stool to the subjects.

89. See notes 126-31 infra and accompanying text.

90. Ashiemoa v. Bani, [1959] Ghana L. Rep. 130; Donkor v. Danso, [1959] Ghana L. Rep. 147. 
it would be repugnant to "natural justice, equity and good conscience."01 Further, courts have repeatedly held that a subject may maintain an action against his stool in defense of his usufructuary interest, 92 and may impeach any disposition of such interest effected without his consent, in favor of a third party. ${ }^{03}$ The usufruct retains its traditional incident of heritability. ${ }^{\text {of }}$ It persists in perpetuity, determining only upon express abandonment of the land or failure of the usufructuary's heirs. One of the most notable incidents of the new usufruct is the enhanced power of alienation which it assures to the subjectusufructuary. In the days of Chief Justice Brandford Griffith, the right to alienate out and out was recognized as an incident of the new "freehold" which the courts enthusiastically proclaimed to be vested in the subject. With the eclipse of the "realist movement" during the second quarter of this century, however, little was heard of this right. Afterwards, the first significant modification of the rule against outright alienation of land by the subjectusufructuary took the form of making the stool's consent a precondition of a valid alienation..$^{95}$ Innocuous as this appears, it meant the admission, albeit

91. [1959] Ghana L. Rep. 130, 133; [1959] Ghana L. Rep. 147, 149.

The invocation of the doctrine of repugnancy is a recognized teclnnique for judicial legislation in the administration of customary law in the British Empire. Wherever customary law was saved by imperial law, an exception was made in the case of rules regugnant to "natural justice, equity and good conscience" or a similar formula. The old Courts Ordinance, 1876, § 19, 1 LAwS of THE GoLd CoAst c. 7 (1920) thus provided:

Nothing in this Ordinance shall deprive the Courts of the right to observe and enforce the observance, or shall deprive any person of the bencfit, of any native law or custom ... not being repugnant to natural justice, equity, and good conscience, nor incompatible either directly or by necessary implication with any ordinance for the time being in force.

Two considerations weighed with colonial judges in declaring a customary doctrine inadmissible on the basis of the repugnancy clause. In some cases, the judges were concerncd to inject English ideas of justice to "temper the rigors of native law." In others, the formula was merely invoked as an excuse for declaring a particular doctrine of native law as obsolete. It is submitted that the latter consideration weighed with the Courts in proscribing the custom mentioned above.

92. Tawiah v. Gyampoh, 3 W. Afr. L. Rep. 293 (1957); Ohimen v. Adjei, 2 W. Air. L. Rep. 275 (1957).

93. Donkor v. Danso, [1959] Ghana L. Rep. 147; Oblee v. Armah, 3 W. Afr. L. Rep. 484 (1958) ; Baidoo v. Osei, 3 W. Afr. L. Rep. 289 (1957).

94. See Oliennu, Princtples of Custodrary Land Law in Ghana 57 (1962). Since the family constitutes the "heir" in the customary law of intestate succession, it follows that continued devolution of the interest will be assured until the death of the last member of the maximal lineage. The familiar statement that the usufructuary interest lasts so long as the subject and his "heirs" continue to recognize the superior title of the stool does not embody words of limitation delineating the quantum of the usufructuary interest, but merely emphasizes the fact that the subject's interest is an incident of his civic status. His allegiance to the stool which involves recognition of the stool's superior title, is the fundamental premise on which the whole edifice of his rights, including his proprictary rights. is anchored. Within the framework of the stool-subject relationship, which must exist in order to give rise to the usufruct, the subject's interest is potentially perpetual.

95. See Golightly v. Ashrif, 14 W. Afr. Ct. App. 676 (1955); Owiredu v. Mfoshic, 14 W. Afr. Ct. App. 11 (1952). 
a limited one, of the subject to what was hitherto an area exclusively within the competence of the stool, although the prior reference to the stool ensured that it would retain its jurisdictional rights, as well as the formal indicia of its dominium of the land so alienated. Buor v. Bekoe ${ }^{96}$ made this new rule even more significant by holding that a sale by the subject without the stool's consent rendered the disposition merely voidable, not void, and that laches on the part of the stool in upsetting the alienation would bar its impeachment.

The next important expansion of the subject's right of alienation occurred in a string of decisions ${ }^{97}$ dispensing with the requirement of the stool's consent if the conveyance expressly stipulated a covenant binding the alience to recognize the superior title of the stool and to perform the customary services formerly due from the subject-alienor. The courts went so far as to declare that any other conditions which the stool purported to impose upon the subject prohibiting or abridging the right to alienate without the previous consent of the stool would be void.

Thus the only vestige of the former ban on alienation by the subject is a verbal formula by which the subject-alienor and the stranger-alienee pay lip service to the stool's dominium. ${ }^{88}$ Although the court employs the new technique of designating the subject's interest as a usufruct, the subject matter of the transfer is, in effect, the ownership of land. The covenant for services to the stool which now replaces the stool's consent has little significance ontside judicial decisions. In the first place, stools rarely insist on the performance of customary services, which have now fallen into desuetude. ${ }^{90}$ Secondly, conveyancing practice does not reflect the necessity to stipulate for the performance of services in outright alienations by the subject. The legal profession hardly adverts to the covenant for services when drafting transfers of the subject's interest in land. An examination of conveyancing terminology in Ghana will reveal a fascinating computation of words of limitation depicting an unencumbered title. The subject is said to convey his interest "in fee simple" or "absolutely" or "absolutely forever" or "forever absolutely" or "in fee simple free from all encumbrances." Though use of English words of limitation is patently incongruous in the Ghanaian situation, the usage nevertheless may be regarded as a crude way of registering the evolution of an interest closely analogous to the common law freehold.

The only situations in which the stool's radical title has a proprietary significance in respect of land appropriated by the subject are where the land has become bona vaccantia, in which case the land vests in the stool free from

96. 3 W. Afr. L. Rep. 26, 29 (1957).

97. E.g., Kotei v. Asere Stool, (unreported decision of Privy Council appeal No. 31 of 1959) (1961), 5 J. African L. 180, 185-86 (1961); Thompson v. Mensah, 3 W. Afr. L. Rep. 240 (1957).

98. Thompson v. Mensah, supra note 97 , at 248 .

99. If the occupants of stools knew the customary law, they would at each annual festival claim from stranger purchasers of lands customary tribute.

OLLENNU, op. cit. supra note 94, at 53. 
all encumbrances, and where the land is subject to compulsory purchase order by the Central Government.100

The new usufructuary title has been described as "inheritable and alienable either by transfer inter vivos or by testamentary disposition."101 Traditionally, a subject could dispose of his usufruct by samansiw - a nuncupative death-bed declaration which was a cross between an inter vivos gift and a devise. Whatever its conceptual classification may be, samansiz was only effective in so far as the kinsmen of the decedent were willing to comply with the dispositions. However, with the reception of English forms of disposition, there has been increasing recourse to the common law will for the purpose of devising selfacquired land, and a testator using a common law will has been allowed the same freedom of disposition as his English counterpart.

Some writers have challenged the consequences of this assumption and have maintained that the adoption of the English will form does not necessarily involve the importation of the substance of the English law of wills.102 A Ghanaian's common law will, they would argue, is no more than a memorandum of the samansize and must be approved by the testator's family to be valid. On the other hand, the introduction of such common law forms as conveyance and mortgage by deed has not merely provided Ghanaians with colorless, if more efficient, devices for transferring interests subject to customary law, without any impact on the substantive body of customary law. As we have demonstrated, the stool's dominium has been denuded of its substance by the practice - plainly recognized by the courts - of subjects alienating an "estate in fee simple" out of their usufruct. Similarly, Ghanaians who resort to the common law will do so fully conscious of the doctrinal implications of this form. In a society in which the definition of a man's matrilineal family excludes his wife and children, fathers have manifested a growing concern to

100. The radical nature of the alienation involved in such compulsory acquisition is such that it precludes the barest fiction of the stool's absolute title, manifested in the persistence of rights of overlordship and the possibility of reverter. Such alienation passes to the Central Government "an absolute and indefeasible right to lands free from all adverse and competing rights, titles, interests, trusts, claims and demands whatsoever." This has been construed as ousting the stool's jurisdictional rights, as well as all proprietary interests previously held in the land. The Courts have accordingly been compelled by the strict logic of doctrine to hold that only a stool can convey the land in a compulsory purchase situation. See In re Osu Mantse (Claimant), [1959] Ghana L. Rep. 163. Compensation in respect of such acquisition is therefore payable to the stool in the first instance, though the subject-usufructuary is entitled to an appropriate share thercof. Note, hovever, that the interposition of a conveyance by the stool is dispensed with under the State Lands Act $\S 1$, Acrs of GHANA (1962), whereby the mere publication of an executive instrument designating a piece of land as required in the public interest suffices to vest it in the President. This further diminishes the significance of the stool's dominium.

The decisions relating to alienation by sale equally apply to alienation by mortgage.

101. OLIENNU, op. cit. supra note 94 , at 57 .

102. E.g., Aliotr, Essays IN African Law 263 (1960) who supports his assertions with a quotation from Lingley, J., in Andoh v. Franklin (unreported decision of the Land Court, Cape Coast, Land App. No. 50/1950) (1952). 
divert part of their estate from the normal line of devolution in order to provide for their wives and children, and the common law will provides a convenient device for placing property out of the reach of their families who would otherwise inherit their estate. Official policy and progressive thinking in Ghana have always supported this practice, ${ }^{103}$ and the courts have accordingly given effect to wills without reference to the wishes of the decedent's family.

The overall effect of current decisions, then, is to transform the usufruct from indefinite rights of user into an estate in stool land which is transmissible, alienable and potentially perpetual, and which admits of practically no limitations on user. Analytically this interest is no longer a mere qualification of the sovereign's final title, in the sense of ius in re aliena, but an estate which confers upon the subject a species of ownership coexistent and simultaneotus with the stool's ownership. ${ }^{104}$

Honore has advanced the thesis that the concept of ownership in a mature system of law comprises the following elements:

The right to possess, the right to use, the right to manage, the right to the income of the thing, the right to the capital, the right to security, the rights or incidents of transmissibility or absence of term, the prohibition of harmful use, liability to execution, and the incident of residuarity. ${ }^{.06}$ On these criteria, the subject's interest has all the indicia of ownership. He enjoys the exclusive right to the possession of the land appropriated by him unthreatened by the concept of adverse possession. He has always been assured the right to use even under traditional law. $\mathrm{He}$ alone grants all licenses in re-

103. The authorities in Ghana have, within the past few years, been considering the promulgation of a uniform succession code prescribing a fixed order of intestate succession for all communities in the country. The proposals under current discussion show a distinct bias in favor of the children of the decedent. Thus the Marriage, Divorce and Inheritance Bill, 1963, ordains that the major portion of the decedent's estate should devolve upon his children, while virtually excluding the family from succession.

104. For an indication that this transformation has not gone entirely unnoticed consider the following diagnosis of Lord Denning in Kotei v. Asere Stool (unreported Privy Council Appeal No. 31 of 1959) (1961), 5 J. AfricAN L. 180, 185-86 (1961):

Their Lordships have been referred to a series of decisions in the Land Court in recent years, affirmed on occasion by the Court of Appeal, from which it appears that the usufructuary right of a subject of the stool is not a mere right of farming with no right to alienate. Native Law or custom in Ghana has progressed so far as to transform the usufructuary right, once it has been reduced into possession, into an estate or interest in land which the subject can use and deal with as his own, so long as he does not prejudice the right of the paramount stool to its customary scrvices. He can alienate it to a fellow-subject without obtaining the consent of the paramount stool, for the fellow-subject will perform the customary services. Ho can alienate it to a stranger so long as the proper provision is made for commuting the customary services. On his death it will descend to his family as family land except in so far as he has disposed of it by will, which in some circumstances he may lawfully do. The law on the subject is developing so rapidly that their Lordships think it wrong to limit the right of the plaintiffs in the way that Jackson, J., did.

105. Honoré, Ozenership, OXford Essays in JuRISpRUdence 107, 113 (Guest ed. 1961). 
spect of the user of the land, he may contract with any person for an abunu or abusa agricultural tenancy, for a lease, or for a mortgage or a customary pledge without reference to any authority, and he is entitled to the income from the land. ${ }^{106}$

As regards the right to the capital, ${ }^{107}$ the customary notions of fiduciary responsibility to the ancestral spirits and the strong bias in favor of preserving land for posterity formerly ruled out the extreme individualist conception of the right to abuse property; but, with the disintegration of the fabric of traditional religious and social ideas, as evidenced by the large scale alienation of land in the early part of this century, it can no longer be confidently asserted that Ghanaian concepts of ownership are free even of these individualist excesses. As far as the right to security is concerned, we have seen that in the customary conception, as enunciated by the Courts in recent times, the usufructuary interest is practically inviolate, though there is no immunity from compulsory acquisition by the central government in the public interest. The usufructuary interest is also characterized by indefinite transmissibility. Finally, the usufructuary interest has the element of residuarity. Upon the expiration of a lease, or of abusa or $a b u n u$ tenancies, or upon the determination of a pledge, the usufructuary resumes his ownership rights free from all encumbrances.

\section{The Involvenent of the Republic In the Ownerseip, CONTROL AND USE OF LAND}

Modern trends in Europe and America indicate an eclipse of the extreme, individualistic conception of private property. ${ }^{108}$ Recent developments in Ghana are no exception to this phenomenon. Since independence, there has been a marked increase in the land capacity of the central government. A rapid succession of statutes has armed the Republic with far-reaching powers to expropriate land, to control user and actually to administer a considerable sector of landed property. This development would probably strike the Western jurist as staggering unless he had some appreciation of the historical background.

In pre-colonial days, Ghana was a conglomeration of independent states, each with its self-contained scheme of landed interests. Even where these states formed a federation, as they did in Ashanti, the political association did not entail the surrender of ownership of land to the federal authority. The establishment of British rule raised, for the first time, the question of the proprietary powers of a supra-state authority. Against the promptings of the more robust imperialists, the British Crown did not assert ownership of Ghana land in consequence of colonization. ${ }^{108}$ When the British later attempted to declare unoccupied lands Crown lands, ${ }^{110}$ Ghanaians successfully resisted the

106. See generally Oblee v. Armah, 3 W. Afr. L. Rep. 484,489 (1958).

107. See Honoré's definition of the "right to manage". Honoré, supra note 105, at 123.

108. See, e.g, Potter, Caveat Emptor, 13 Convey (n.s.) 36 (1948-49); Cross, The Diminishing Fee, 20 LAW \& Contesro. Prob. 517 (1955).

109. See REDWAR, op. cit. sipra note 54, at 68 .

110. See discussion of Public Lands Bill 1897, in MeEk, Laxn Law asto Custox in THE CoLonies 170 (1946). 
measures as confiscatory, on the theory that, by customary law, such unoccupied lands were already vested in the stools in whose jurisdiction they were situated. ${ }^{111}$ Apart from appropriation of mineral rights in the Northern Territories, ${ }^{112}$ the colonial government was constrained to limit its powers to the regulation of user and beneficial enjoyment, especially in the case of the alienation of land and the grant of concessions to foreign speculators, and the exercise of eminent domain upon payment of full compensation. ${ }^{113}$

With regard to the regulation of user, the Government did not act until 1900,114 after the various stools had granted concessions over a substantial portion of Ghana land. Even then the colonial government exercised mere policing powers over these agreements. At the time of independence, then, the whole known mineral resources of the country were subject to concession agreements between stools and foreign concerns. The legacy of the British to the post-Colonial Government was one of minimal involvement in land ownership. This was not particularly welcome to a government which saw itself as assuming a leading and an unequivocally bold role in the social and economic development of the new country. Nor, indeed, did such a laissew faire approach prove beneficial to the public interest of Ghana in colonial days. Professor Hancock, the eminent imperial historian, has pointedly observed:

The relations which ensued between concession-hunters, chiefs and the Government illustrate very forcibly the paradox that a government which wished to dispossess a native people could hardly do better than to proclaim the principle of absolute ownership by native communities. ${ }^{116}$

Not suprisingly, the philosophy which pervades modern legislation relating to land is grounded on the fundamental premise that property must serve the greater interest of the whole community. ${ }^{116}$

Stool lands have particularly attracted the concern of the new government because of both a notorious tradition of misuse by the stools and the general decline of traditional authority. Recent legislation arming the Republic with sweeping powers revolves around four themes: the conservation of natural resources, control of land use, enhanced powers of expropriation, and the assumption of the managerial and fiduciary powers of stools in respect of unencumbered stool lands.

With the reduction of stools to the status of subjects in the larger framework of the Republic of Ghana, it became clearly desirable to proclaim Republic ownership of all minerals in Ghana. The charge of confiscation by an

111. The principle was judicially endorsed in Wiapa v. Solomon, [1905] Ren. 410.

112. Minerals Ordinance, 2 LAws of THE Gold Const c. 131 (1937).

113. Public Iands Ordinance, id., c. 113; Administration (Northern Territories Ordinance). Id., c. 95, $\$ 5$.

114. The year the first concession act was passed.

115. 11 Hancock, Survey of British Commonwealth Affairs 182, quoted in MEEK, op. cit. supra note 110 , at 170 .

116. The Republican Constitution provides: "... no person should be deprived of his property save where the public interest so requires, and the law so provides." GrinNa CoNST. part III, § 13(1). 
alien government had no application in an independent Ghana; and the irresponsibility which had characterized the grant of mineral concessions by the various stools called for a radical overhaul of the ownership patterns. Thus, while expressly saving the vested rights of concessionaires under concessions previously granted by the stools, the Minerals Act, 1962, declares that all minerals are "... vested in the President on behalf of the Republic of Ghana in trust for the people of Ghana."117 The Government has clearly avoided a policy of nationalizing those mines which are still exploited by foreign concerns, but has established the legal basis for absolute control of mineral resources which may be discovered at a later date, or which will revert to the state upon the determination of existing concessions. The vesting of minerals in the Republic extinguishes one of the significant incidents of the stool's dominium. .18 $^{218}$ Although the vested rights of existing holders have escaped expropriation, the Concessions Act, 1962, discussed below, confers extensive powers on the Government to initiate proceedings for the revision and determination of concessions when it deems it to be in the public interest to do so, as for example where the consideration issuing from the holder is inadequate, in view of changed economic circumstances. ${ }^{119}$ -

State control of land is manifested in two forms: the regulation of the actual physical user of land and the abridgment of powers of disposition or other incidents of ownership. Local governments now have full zoning and land planning authority, subject to ministerial approval. ${ }^{120}$ Concessions, too, are strictly regulated. Though the Colonial Administration also sought, through the Concession Ordinances of 1900 and 1939, to impose restraints on indiscriminate alienation of mineral, timber and other resources in favor of foreign concessionaires, the aim of the administration was not so much to prevent scandalous exploitation by alien prospectors as to curb the excesses of chiefs insensitive to the well-being of their subjects. The Concession Ordinance,

117. Section 1, Minerals Act, Acts of Grana (1962). As to vested rights in minerals under existing concessions, the Act leaves these intact in substance, but reserves to the State the right of pre-emption of all minerals "raised, won or gotten in Ghana."

118. Other conservatory measures are to be seen in the Forests Ordinance, 1928, 2 LAwS of THE GoLd COAST c. 122-(1937) (amended in 1949), and the Soil Conservation Ordinance, both of which have been preserved. Under the former, the Republic can compulsorily designate an area as a Forest Reserve for the purposes of preventing wanton exploitation of timber or the destruction of forests, to safeguard the water supply, or to "assist the well-being" and "secure the supply" of forest and agricultural crops in the forest and vicinity. Section 2.

The legal effect of a reservation is to vest the land in the "President in trust for the stools concerned," [Concessions Act $\S 16$, Acts of GraNA (1962)] and to abrogate such rights of user and beneficial enjoyment as are prejudicial to the preservation of the forest on such land, but there is no prohibition of such user as collecting forest produce or growing crops which leaves the forest intact. Under the Soil Conservation Ordinance, lands may be "frozen" for the purposes of preserving or reclaiming land and also for the purpose of protecting water resources.

119. Section 3(1).

120. Local Government Act $\S 58(2)$, Acts of GHArs (1961). Compare Town \& Country Planning Act, 1958 (formerly Town \& Country Planning Ordinance), c. 84. 
1939, made judicial supervision of grants of concessions mandatory. ${ }^{121}$ The Courts were empowered to void concessions on certain grounds such as inadequacy of consideration and infringement of the customary rights of third parties. ${ }^{122}$ These provisions, however, utterly failed to arrest the drain of resources from the country, and the principal objective of the Concessions Act, $1962,{ }^{123}$ is to attempt a salvage operation through a regime of rigid controls. ${ }^{124}$ Concessions in respect of stool lands may now be determined or modified by a special tribunal at the instance of the responsible Minister, on a showing that they adversely affect the public interest. ${ }^{126}$ They may also be cancelled by the President "if he considers that it is or may prove prejudicial to public safety or interests." ${ }^{128}$ No provision is made for indemnification for such cancellation to either grantor or holder. The Administration of Lands Act, 1962, reinforces the above limitations by curtailing the quantum of transferable mining, timber and the concession rights. ${ }^{127}$

The Administration of Lands Act, itself a major regulatory measure, ordains that dispositions of stool lands ${ }^{128}$ for valuable consideration "shall be of no effect" without the consent of the government. ${ }^{120}$ Furthermore, the re-

121. Concessions Ordinance, $\S 6$ (No. 19 of 1939).

122. Id. at $\S 12$.

123. This Act replaces the 1939 Ordinance with regard to concessions involving stool lands. The 1939 Ordinance is continued in force with reference to other land.

124. The Report of the Commission of Enquiry into Concessions, 1961, contains an eloquent indictment of the conduct of concessionaries and chicfs. Concessionaires invariably exploited the ignorance of granting Chiefs; in the words of the Report (If 29).

(a) The grantors in most cases did not have any knowledge of the real meaning of the rights they were granting or even of the type of agreement appropriate to mining and timber operations. These grantors seldom had expert legal or economic advice.

(b) Promises were made to the grantors for the provision of social amenitics by the concessionaires which turned out to be of little economic value. Again, although the Ordinance provided for the variation of agreements by consent of both partics, concessionaires were unwilling to consent even when changed economic conditions made variation imperative.

125. Concessions Act, $\S \S 3(1), 4(1)$, Acts of Grana (1962).

126. Id. at $\S 5$.

127. Administration of Lands Act $\S 12$, Acrs of GHANA (1962).

128. The Administration of Lands Act, Acrs of GraNa (1962), defines stool land as "land controlled by any person for the benefit of the subjects or members of a stool, clan, company or community as the case may be and all land in the Upper and Northern regions other than land vested in the President." This means all types of unencumbered community land, but not family land. The sweeping provision with regard to land in the Northern and Upper regions is based on the legacy of the British Government which asserted more substantial proprietary rights in those regions than in the South. See Northern Territories Land and Native Rights Ordinance, 1927, 2 LAws of THE Gord Cosst c. 121 (1937).

The new Concessions Act is a continuation and amplification of the Old Concessions Ordinance, (No. 19 of 1939), the Colonial Administration's answer to the problem of indiscriminate alienation by stools in favor of alien prospectors.

129. Administration of Lands Act $\S 8$, Acts of GruNa (1962). The consternation caused by this provision among traditional authorities has led to the device of resorting to gratuitous transfers of land on paper while making clandestine provision for the payment of valuable consideration to stools; since gratuitous transfers are not caught by the Act. 
quirement of governmental consent applies to a disposition of land "by any person, who by reason of his being so entitled under customary law, has acquired possession of such land either without payment of consideration or in exchange for a nominal consideration."130 This would seem to include the subject's usufruct, which he acquires "by reason of being so entitled under customary law ... and without payment of any consideration". If this interpretation is correct, the act would represent a substantial qualification of the alienability of the new usufruct. Perhaps, however, the provision contemplates only those situations where the subjects' usufruct has not matured into an estate: the provision merely mentions "possession," not "ownership," and there are still situations where the stool subjects' usufruct lacks that element of permanency which is a cardinal indicium of the new freehold.

Recent legislation proclaims a robust conception of eminent domain. The President may, as the public interest dictates, expropriate any private land in the Republic and authorize its appropriation by State officials one month after the initial announcement. ${ }^{131}$ The language of the new act lends itself to the interpretation that the payment of compensation is not mandatory but merely discretionary - "The Minister may ... pay compensation or make an offer of land of equivalent value."182 It may be argued that the discretion vested in him only applies to the choice between the payment of compensation and the offer of land in exchange, but there is no reason why the mandatory "shall" should not have introduced these two courses open to him. Nevertheless, other parts of the act would seem to presuppose the payment of compensation as an integral element of the whole expropriatory process. ${ }^{133}$

With regard to stool lands, the Administration of Lands Act, 1962, assures to the government even more summary procedures for expropriation. Section $7(1)$ of this act ordains: "Where it appears to the President that it is in the public interest to do so, he may, by executive instrument, declare any stool land to be vested in him in trust ... " Subsection 2 of this section provides that any moneys accruing from the trust shall be paid into a Stool Lands Account, administered by the central government. There is no provision for payment of compensation to the stool so deprived. The nearest approximation

130. Id. at $\$ 8(1)(\mathrm{b})$.

131. State Iands Act $\S 1$, Acrs of Grana (1962).

132. Id. at $\$ 4$. But of. Public Lands Ordinance, 2 LAws of tre Gold CoAst c 113 (1937).

133. Thus § 1(2) provides that the executive instrument declaring land to be required in the public interest "may contain particulars in respect of the date on which the land so declared shall be surrendered and any other matter incidental or conducive to the atthinment of the objects of the instrument including ans assessment in respect of the compersation that may be paid." Again under $\$ 4(2)$, a person aggrieved by the Mlinister's assessment of compensation may "refer the matter" to a Tribunal established under this Act for the purposes of adjudicating claims in respect to the land taken by the Government. It may, of course, be argued, with some force, that these provisions do not dispose of the Government's immunity from the obligation to pay compensation; they only come into operation if the Minister does decide to pay compensation in a particular case. 
to indemnification for such deprivation consists in the indirect benefit which may accrue from the sums paid by the Minister out of moneys standing to the credit of the Stool Lands Account, to the local authorities having jurisdiction over the lands expropriated, and in payments made, out of the same account, by the Minister for the benefit of the peoples in the jurisdiction of the stool and particularly for the "maintenance of the stool or other traditional authority including a traditional council." Since the revenue derived from stool lands so expropriated is not exclusively applied for the benefit of the stool and its subjects, expropriation under this section converts stool lands into national assets at the disposal of the central government, subject to the ministerial discretion to allocate a certain proportion of the revenue for the purposes of the locality in question. Thus it would seem, although the section is not explicit, that the beneficiary of the trust created here is the whole Republic. 134 The government clearly regards itself as a natural successor to stool lands with the decline of traditional authority, and does not extend to stools the principle of compensation for deprivation which largely characterizes its dealings with individual owners.

The rationale of recent legislation relating to stool lands is predicated on the principle that stool lands are national assets to be administered by the central government, even though the trappings of ownership may still be vested in stools. Thus the Administration of Lands Act divests stools of the control, and, to a large extent, the beneficial enjoyment of the stool lands, although there has been no deprivation of ownership. The general policy of the act is pithily" stated in its first section: "The management of stool lands shall be exercised by the Minister."'135

134. The Act introduces ingenious devices for appropriating the use of land to the Government without the radical step of divesting titleholders of their titles. Thus $\$ 10$ states:

(1) The President may authorize the occupation and use of any land to which this Act applies for any purpose which, in his opinion, is conducive to the public welfare or the interests of the State....

(3) Where any person suffers special loss by reason of disturbance as a result of an authorization under this section he shall, out of moneys granted by the National Assembly, be paid such compensation as the Minister or, on appeal, an appeal tribunal, may determine.

Section 10 differs from $\S 7$ in several respects. First, $\S 10$ merely empowers the President to authorize the occupation and use of land by state officials, where as $\S 7$ vests ownership of the lands affected in the President. Second, unlike $\S 7, \S 10$ applies to all lands subject to the Act, which means not only stool lands but also the interest of a person who acquired his holding "by reason of his being so entitled under customary law ... without payment of any consideration" - an interest, which, as indicated earlier, looks like the stool subject's usufruct. It may well be that the comprehensive character of the scope of $\$ 10$ accounts for the unequivocal provision for the payment of compensation which $\$ 7$ lacks.

135. In addition to his concurrence in any grant of concession, the Minister's concurrence is required in "any transaction affecting stool lands." Section 8(5). Numerous provisions give the Government positive managerial control. E.g., $\$ \S 2$ (power of President to intervene in litigation concerning stool land to prevent protracted litigation), 14 (power of the Minister to keep all documents in regard to stool land), 16 (power of cviction in 
The increased proprietary capacity of the government has had the following impact on the customary scheme of interests in land: The bold assertion of government control of land makes any concept of absolutist ownership, which recent cases seem to project, quite illusory. The subject's estate may be immune from restrictions by the stool, but is considerably curtailed by the Republic's powers of expropriation and its wide powers of control of user. ${ }^{13 B}$ Furthermore, if the Administration of Lands Act applies to the subject's estate, then ownership will be severely curtailed by governmental supervision of dispositions. Indeed a strict application of the revenue provisions of that act would vest the revenue from the subject's estate in the government. Further, with regard to the effect of recent legislation on the institution of stool lands, it is no exaggeration to assert that the stool's ownership of unencumbered stool lands is now an empty concept devoid of all substance. The decline of traditional authority as a political force has led to the disintegration of its proprietary incidents. The chief no longer administers a political division; this function is vested in a local authority responsible to the central government. The old system of indirect rule through traditional authorities was swept away with the inauguration of an African government at Accra. This government has now consummated the process of denuding traditional authority by stripping it of its proprietary capacity. The administration of stool lands and the revenue accruing therefrom are now vested in the central government, and with that the institution of stool ownership has virtually been relegated to limbo. We have seen how starting from the position of unqualified dominium, the stool's ownership of lands was eroded by the growth of the subject's interest therein, so that stool ownership only had significance in respect of unencumbered stool land. Now the invasion by the Republic has equally undermined the last bulwark of the stool's proprietary interest.

The evolution of the scheme of interests in land has come full circle. Ownership started as a corporate idea vested in the state, formerly excluding any form of distinct individual interests, but later admitting of exclusive, individual possessory interest in the form of the usufruct. Under the impact of new economic and social conditions, and interaction with English juristic ideas, the usufruct matured into a "freehold" interest. This development suffered some eclipse in the courts for some time, but it has been revived in substance though under the color of traditional forms. Now the pronounced involvement of the government in land appears to spell a reversion to the idea of state ownership and individual usufruct, though the full impact of the new legislation is yet to be felt.

Minister). The most significant power of the Central Government is the power of the Minister under $\$ \$ 17-20$ to collect all revenue from stool lands, pay them into a stool lands account, and use them at his discretion for the benefit and general welfare of the people of the area from which the revenue comes.

136. "All lands" referred to in $\S 17$ is much wider than stool lands. But see $\S 8(b)$. 


\section{THE YALE LAW JOURNAL}

\section{VOLUME $74 \quad$ APRIL $1965 \quad$ NUMBER 5}

Charles M. Nathan

Editor-in-Chief

\author{
JoHN GRIFFTthS \\ Owen J. Sloane \\ Allan A. Tuttle \\ Michael A. VARET \\ Note \& Comment \\ Editors
}

JOHN R. ADLER

Jonathan A. Ater

RICHARD J. BRAEMrR

DenNis K. BromLey

E. Edward Bruce

Charles N. Burger

Robert A. Carter

Raymond C. Cleevenger, III

Dennis E. Curtis

Antront A. Dean

Walter E. Delinnger, III

W. LEe H. Dunhau

Roger D. Feldaran

Gregory C. GLyNN

RICHARD GOODYEAR

JAMES S. GORDON

H. JefF Greenfteld

Michael F. Halloran

JAMES T. B. TRIPP

Business Manager

\author{
Daniel Marcus \\ Topics Editor \\ Charles Donatue, Jr. \\ Sherwin M. GolduaN \\ Article \& Book \\ Review Editors
}

\section{Martin E. Lowy \\ Managing Editor}

Charles H. Herz

B. Boyd Higet, JR.

C. Stephen HowArd

George L. Jurow

Lindsex C. Y. KaANG

HowaRd A. KNIGHT

Martin D, KratL

StMoN Lazarus, III

BETSY LEVIN

RoNALD F. LIPP

Philip R. LOChNer, JR.

Cameron F. Macrae, III

Frederick B. McLANe

Rod McMahan

LEONARD M. MARKS

ANITA S. MARTIN

JOSEPH ONEK

\author{
Barbara H. Paul \\ Edward A. Peretl. \\ Charles A. Pulaski, Jit. \\ Davto A. Ramm \\ LEONARD M. ROSS \\ FrEd E. SCHART \\ Benno C. Scrasudr, Jn. \\ Philit Gordon Schirada \\ LARRY G. Strion \\ Alan D. Sistrsky \\ Alan George Srenling \\ Leonard P. Stricieman \\ WilLARD B. TAYLOR \\ David F. Tillotson \\ Michael S. Wald \\ Mark A. Walkeer \\ ROBERT F. WALKER \\ Peter L. Zimrota
}

\section{Berila Seidenanum \\ Business Secretary}

\section{CONTRIBUTORS TO THIS ISSUE}

RoBERT H. BorK. B.A. 1948, University of Chicago; J.D. 1953, University of Chicago.

Sarruec K. B. Asante. LL.B. 1956, Nottingham University; LL.M. 1958, London University.

Peter Juviler. B.E. 1948, Yale University; M.A. 1954, Columbia University ; Ph.D. 1960, Columbia University.

Stanford G. Ross. B.A. 1953, Washington University (St. Louis) ; LL.B. 1956, Harvard University. 